\title{
Long walk to knowledge : On the determinants of higher education mobility to Europe ${ }^{\text {厺 }}$
}

\author{
Jonas DIDISSE ${ }^{a}$, Thanh Tam NGUYEN-HUU, ${ }^{a, b}$, Thi Anh-Dao TRAN ${ }^{a, *}$ \\ ${ }^{a}$ CREAM-EA 4702 (University of Rouen) \\ Faculty of Law, Economics and Management \\ 3 avenue Pasteur - 76186, Rouen cedex, France. \\ ${ }^{b}$ TIMAS, Thang-Long University \\ Nghiem Xuan Yem read, Hoang Mai District - Hanoi, Vietnam
}

\begin{abstract}
This paper investigates the determinants of demand for higher education mobility from students in low- and middle-income countries to European countries over the period 2004-2013. We identify the dyadic factors associated to the relationships between home and host countries as well as monodic variables associated to "push" and "pull" factors. Used together with various linguistic relations, we emphasize the relevance of informal and formal networks in explaining resistance to migration of students. All put together, our results show that factors that are origin and destination specific like socio-demographic characteristics, individual beliefs and institutional profiles, out of the usual economic considerations, have a significant impact on student mobility.
\end{abstract}

JEL codes: F22, F62, I23, O15, O57

Keywords: Higher education mobility, Network effects, Language skills, Institutional quality

\section{Introduction}

International mobility of people is booming globally since the early 1990s. All countries experience out - as well as in - migration by people looking for better opportunities to work or to study. The main reason why so many people would like to leave their home country is that they may earn much more if they move (the so-called "place premium"), with economic outcomes on labor markets and economic growth both at home and in destination countries. But there are other reasons for moving to another country besides income gains. Among them, Higher Education (HE) in a globalizing World has gained growing interest in the economic literature. As summarized in OECD (2009):

"Higher Education drives and is driven by globalization. Higher education trains the highly skilled workers and contributes to the research base and capacity for innovation that determine competitiveness in the knowledge-based global economy. It facilitates international collaboration and cross-cultural exchange. Cross-border flows of ideas, students, faculty and financing, coupled with developments in information and communication technology, are changing the environment where higher education institutions function. Cooperation and competition are intensifying simultaneously under the growing influence of market forces and the emergence of new players."(p.13)

\footnotetext{
The authors wish to thank Arnaud Elie (CREAM, University of Rouen), Sylvain Lamourette (Head of International Relations Office and EU Project Manager, University of Rouen) and Jorge Santos (Department of International Cooperation, University of Porto, Portugal) for their helpful comments, precious assistance in data compilation of immigration policies, student mobility and Erasmus Mundus scholarship programmes. Any errors or omissions are the authors' responsibility. The views expressed in this paper are solely those of the authors and should not in any way be attributed to the University of Rouen.

${ }^{*}$ Corresponding author.

Email addresses: jonas.didisse1@univ-rouen.fr (Jonas DIDISSE), huu-thanh-tam.nguyen@univ-rouen.fr (Thanh Tam NGUYEN-HUU), thianh-dao.tran@univ-rouen.fr (Thi Anh-Dao TRAN)
} 
In the light of this, globalization has implied a changing understanding of HE. Especially, developing countries need to understand and to better exploit the benefits as well as mitigate the challenges that come with globalization. On the one hand, internationalization of HE has challenged policy makers and university managers in various terms: the importance of the English or foreign languages, the need for internet and other forms of Information and Communication Technology (ICT), the emphasis on research and publications and the related concern with the ranking of universities, etc. But on the other hand, cross-border or "borderless" HE has also changed students' and staff behavior. The movement of persons and programmes across nations has opened new opportunities in terms of careers and salaries, skills and learning or teaching capacity. The development of mobility programmes in the frame of the Erasmus scholarships financed by the European Commission aptly illustrates such opportunities.

International students who study abroad are an example of legal temporary migrants who have been rising during the last recent decades. Besides that, the OECD provides the trend in the percentage of graduates of tertiary education among the youth population, and the figures show a gradual but definite increase in the percentage. With the increase in the number of entries at tertiary level, a changing global landscape for HE is underway where global competition among educational institutions in developed countries is on the rise in order to attract both native-born and international students (van der Wendet, 2015).

By focusing on the demand for HE, the present paper aims at studying the determinants of student mobility from developing countries to Europe. But it takes a new view on the topic: especially, it wonders if non-monetary factors like linguistic relations, networking or institutional factors and beliefs may explain the flows. From the point of view of the sending countries, individuals demand for foreign study and sort across potential destinations. A random selection in the origin may then face "positive" selection in the destination, that is: high-skilled people are more likely to become immigrants and are randomly selected from the population of immigrants in the destination. The key question is then: what are the determinants of HE mobility in a Southern perspective? Where do students go? This allows us to address three underlying issues:

(i) First, what are the main motivations for students from developing countries to go abroad? What are the factors that encourage or inhibit this mobility will in the host countries? While the former determinants are gathered in the so-called "push" factors characterizing sending countries, the latter deal with "pull" factors stemming from destination countries.

(ii) Second, are there any individual or environment characteristics which influence mobility to one location compared to the others?

(iii) Third, does the current combination of mobility and funding flows through scholarship programme help student mobility? What will be the implications of these trends for the geography of Europe's HE? Indeed, global competition among HE Institutions (HEIs) to attract internationally mobile students raises worrying concerns on global scientific powerhouses and thus global magnets for academic talent. ${ }^{1}$ One wonders if the current uneven geography of academic mobility may also be guiding future mobility of students and, through a cumulative causation, an even stronger concentration may occur.

To conduct our investigation, two strands of literature are crossed here in the field of international development studies:

- On one side, the economics of immigration which deals with the factors underlying international mobility, i.e.; what determines whether people choose to move, and where they decide to go. We rely here on the new economics of migration paradigm, and focuses on student migration as a collective decision that results from incomplete markets (Bansak et al., 2015).

- On the other side, we consider cross-border education at tertiary level as an investment decision in human capital theory. Notably, students are individuals seeking better opportunities

\footnotetext{
${ }^{1}$ In the OECD countries for example, more than 3/4 of mobile academics are concentrated in only 4 countries: namely, the US, Australia, the UK, and Japan.
} 
to get education (academic and skills) in order to increase their future earnings and employment opportunities. Theories of investment in education may then tell us why international mobility at tertiary level is worthwhile.

The rest of the paper is organized as follows. Section 2 briefly describes our statistics and background. Section 3 presents the general options of our methodological approach before reporting our empirical findings in Section 4. Section 5 summarizes the results and concludes.

\section{Research framework}

\subsection{Targets}

There are different types of immigrants with sometimes overlapping groups. This is because of the variety of sources of migration. Here, we focus on immigrants who choose to move legally (not forced to do so) because most of the world's migrants are voluntary migrants. These voluntary migrants choose to move for various reasons: to work, to join family members or to study. In the present paper, we are interested in educated or skilled people who are going abroad to study for a while and may return home (temporary versus permanent migration). Those persons have permission to enter and live, even temporarily, in a host country. But they can become "illegal or irregular" immigrants by violating the terms of visa (for example, by overstaying a temporary visa and not leaving when they are supposed to). Therefore, immigration policy can affect whether people choose to become permanent migrants and do not return to their origin country. In addition, they can be eligible for public assistance programmes in some host countries, enabling domestic residents to argue against immigrant entries. ${ }^{2}$ Due to the latter point, we take national borders for granted like usual studies in this field, that is: barriers to mobility of people do exist, and policymakers focus on effects of migration flows (here, internationally mobile students) on their own country, not global effects (Bansak et al., 2015).

The purpose of this paper is to examine what drives macro-economic flows of tertiary students from developing countries to Europe. However, by assuming that they will return back to their countries of origin directly after mobility, we leave aside the underlying issue about their decision to stay or not in the destination country, that is: the comparative expectations about future earnings once their studies are completed. To this end, we consider internationally mobile students coming from low and middle income group aggregate (all developing economies). Data that are computed here comes from the UNESCO website on global flow of tertiary level students. Based on its annual data collection, the UNESCO Institute of Statistics (UIS) produces a range of indicators to track trends in tertiary education at the global, regional and national levels. ${ }^{3}$ Internationally mobile students are defined as those who have crossed a national or territorial border for the purpose of education and are now enrolled outside their country of origin. These data are downloaded from the UNESCO website for 89 Low- and Middle-Income countries (LMIs) in destination to Europe over the period 2004-2013. The full list of host and home countries in our sample is presented in Appendix A.

Using the available data, descriptive statics are displayed in Appendix B. Among the various categories of migrants, internationally mobile students are the ones who have experienced a dramatic increase in the last decades. Their number has doubled between 1999 and 2013 (Figure B.1). From the home perspective, $67.2 \%$ of the students outflows originate from Asia (which forms the largest group), Africa and South America (Figure B.2). As a result, LMIs represent $65.4 \%$ of student outflows, hence the importance of a specific analysis for these countries (Figure B.3). At destination, North America and Europe account for $68.6 \%$ of the total aggregate flows with a high concentration in a few number of countries (the US, the UK, France, Germany and Australia). As

\footnotetext{
${ }^{2}$ People may oppose immigration because they believe they will compete with immigrants or will pay more in taxes as a result of immigration (taking their jobs or spots in universities that would otherwise go to native-born students, receiving more in public assistance, or leading to changes in their country's culture). Such beliefs are likely to affect how people feel about immigration, including international students, and are among the reasons why countries impose restrictions on immigration and why immigration policy generates considerable debate (Bansak et al., 2015).

${ }^{3}$ See more at: http://www.uis.unesco.org/Education/Pages/tertiary-education.aspx\#sthash. I4ezWA3x. dpuf
} 
the European countries accounts for $44.3 \%$ of the total aggregate flows, one wonders if the region can become a magnet within global competition among HEIs to attract internationally mobile students (Figure B.2). Figure B.4 shows the evolution of tertiary students flows from LMIs towards our European countries of destination over the period 1999-2013. Out of the number of LMIs counted according to the World Bank classification, our sample of 89 origin countries correspond to a great part of the inflows.

\subsection{Variables of interest}

Different variables can influence the international mobility of students. We divide them into two groups: dyadic factors and monodic factors. The latter include two sub-groups: monodic home ("pull") factors and monodic host ("push") factors.

\section{Dyadic factors}

Moving is costly and requires significant expenses (passport and visa, transportation, and so on), even though they have been fallen over time (Bansak et al., 2015). There are also non-monetary costs to moving which may be even higher than the monetary costs ("psychic costs" for example). Among them, a first set of dyadic variables that are commonly used in gravity models helps to understand what can explain resistance to any bilateral flow, namely: bilateral distance, linguistic proximity, historical colonial links. The CEPII has made available a "square" gravity dataset for all world pairs of countries (Head et al., 2010). These dyadic factors linking home and host countries in the gravity equation are usually applied to international trade, but they can be merged with any matrix of bilateral flow (FDI, migrations, or other types of bilateral flows). Therefore, we assume here that such dyadic variables influence the cost of student mobility.

However, geographic and cultural distances are customary mobility costs which are not specific to students: instead, a student must consider extra-costs of attending a HE programme in a different location into his investment decision. In the present study, it is expected that various measures of networks as well as foreign language skills may lower the cost of migrating, especially when developing countries are considered. Therefore, such considerations are highlighted here by extending the usual dataset provided for gravity models with two other kinds of "resistance".

Linguistic relations are considered to be a first resistance to migration. The contributions of such relations are of particular importance in international HE mobility because language skills allow migrant students to shrink their "sunk costs". However, it seems that the role of this variable is underestimated in the literature since in numerous studies only one measure of language linkage is used. For example, Beine et al. (2014) only refer to "Common official language" while Van Bouwel and Veugelers (2013) base on "Common spoken language" and Vogtle and Windzio (2016) use the "Same language branch". Unlike these authors, we refer to four measures of language relationships which are computed by Melitz and Toubal (2014):

(i) Common official language (COL): An official language implies that "all messages in the language are received by everyone in the country at no marginal cost, regardless what language they speak". This variable takes two values: 1 if two countries share the same official language and 0 otherwise.

(ii) Common spoken language (CSL): it is the probability that a random pair of individuals from two countries can understand each other in a given language. Since a pair of countries may share different spoken languages, CSL can be calculated as:

$$
C S L=\max \alpha+(\alpha-\max \alpha)(1-\max \alpha)
$$

where $\alpha:=\alpha_{i j}=\sum_{l=1}^{n} L_{l i} L_{l j} ; L_{l}$ is the percentage of speakers of a typical language $l$ and $n$ is the number of spoken languages that two countries share.

(iii) Common native language (CNL): it refers to a probability that a random pair of individuals from two countries speak the same native language. The measure of this variable is similar to the CSL. Hence, it follows that CSL includes CNL and is greater than CNL. 
(iv) Language proximity (LP): it implies the closeness of two different native languages. Melitz and Toubal (2014) propose two indicators of LP: the Ethnologue classification of language trees between trees, branches, and sub-branches and the Automated Similarity Judgment Program. In our study, the latter is used to capture the LP.

Turning to our second resistance, the role of networks has been widely investigated in the economic literature. Networking deals with the interest in how social and institutional relationships play an important role in human capital accumulation. In our specific case, we wonder if individuals who are tied to other individuals within social or institutional networks are more prone to become mobile.

A commonly used proxy of network is the stock of all migrants from the origin country living at destination (see for example Beine et al., 2011, 2014; Bertoli and Fernández-Huertas Moraga, 2015). Those migrants are likely to provide assistance and information to students from their country of origin and therefore decrease their migration costs. However, according to the World Bank, international migrant stock is defined as the number of people born in a country other than that in which they live, including refugees or asylum seekers. Therefore, it embodies a broader population than the targeted one, allowing us to introduce two other measures of networks.

A first way to proxy networking is to compute the average number of tertiary students from an origin country moving to a destination country in the last years. Social networks of friends or previous students are informal, but we assume that they are critical determinants in individual decision to study overseas.

The role of informal networks in international HE has been addressed in qualitative case studies from sociological perspectives (see for example Mazzarol and Soutar, 2002; Brooks and Waters, 2010; Beech, 2015; Pedro and Franco, 2016). This approach argues that international mobility is often socially embedded and highly influenced by either friendship or kindship networks. Beech (2015) for example, documents that such networks may provide advice and encouragement, share living experiences that could have a decisive influence on potential students mobility. Our research enlarges these studies by using a quantitative investigation instead of a qualitative approach. As in Beine et al. (2014), we expect that previous students have assimilated many information about the destination country and, across their feedback, share knowledge on it and help to reduce the cost of moving there.

A second proxy of network effects consists in looking at formal partnerships which have been established among HEIs in sending and destination countries. In particular, the Erasmus Mundus - Action 2 (EMA2) programme, which is dedicated to the development of relations between Europe and other regions through international mobility, has become a growing used tool in the internationalization process. This action has the main objectives of promoting intercultural understanding and exchange of persons and knowledge in order to develop HE teaching and learning capacity, and to build the management capacity of HEIs in third countries. In fact, it aims primarily at contributing to the socio-economic development of the non-EU countries targeted by the EU external cooperation policy: we talk about "Lots" of covered countries, or "Eligible" partner countries. To this purpose, grants are awarded to students (from Bachelor to Post-doctorate) and to academic and administrative staff. ${ }^{4}$ Moreover, to be eligible for any EMA2 scholarship, applicants must meet a set of minimum requirements. Targets are clearly defined in terms of mobility flows (host/home institutions, cohorts), disciplines and academic offers (courses, internships), and in terms of candidacy (students, staff). Among the main questions that are raised by such programmes, one wonders if the underlying eligibility criteria of mobility which is offered by EMA2 (area of study, type of mobility, language requirements, partner institutions) lowers resistance to international mobility of students.

\section{Monodic factors}

Monodic variables are a set of variables which capture home or host country specific characteristics. Various strands of the economic literature study the factors which influence the choice of

\footnotetext{
${ }^{4}$ Among the people eligible to EMA2 scholarship, note that some are very short-term migrants (e.g., one full month for academic and administrative staff). They travel to another country "to visit" for a specific period but not to live; they are not considered immigrants, even temporary ones.
} 
HEIs from different perspectives. While aspects on destinations are gathered into "Pull factors", the ones which determine individuals from sending countries to move abroad are synthesized into "Push factors". Push factors are conditions that propel students to leave the origin country, while pull factors are conditions that entice students to enter a destination country rather than another. Both push and pull factors are at play in the decision for a student to become a mover (Bansak et al., 2015). Virtually, every push factor has a corresponding pull factor, and vice-versa. But more specifically, regulatory policies, as well as deep political and institutional characteristics of countries, have been shown to influence trade as modeled in the gravity framework (Shepherd, 2012). In the present study, we believe that such "behind-the-border barriers" aptly apply to migration flows, especially when they are concerned with international mobility of students.

To address the issue, a number of economic and socio-demographic conditions will be tested in determining how economic development influences student mobility. But on the other side, individual perception on public institutions, civil society or social cohesion in home and host countries is of great importance in mobility decision. The objective here is to investigate the effects of institutional factors and beliefs on, or to describe a specific environment underlying mobility choice. Quality considerations, migration climate, expectations and social relations are especially highlighted here.

From a host country point of view, the ability of a country to attract talent from around the world on a highly competitive basis allows their institutions to further strengthen their capacity, improve their rankings and also their reputation. Quality considerations in HE are widely addressed in this perspective (Van Bouwel and Veugelers, 2013). In the same manner, many countries try to limit the number of immigrants entering their country but also to shape the characteristics of the inflow, including internationally mobile students. The policies that destination countries adopt play a central role in determining how many people study abroad and where they go.

Unfortunately, the empirical literature on international student mobility devotes much less attention to the impact of such policies on sending countries. Let's take the provision of public services: according to the existing studies, an inflow of foreign-born HE students may put pressure on the education system and other publicly provided services. Keeping fiscal costs unchanged (and the resulting price of HE unchanged), this inflow increases the demand for HE and could crowd out natives from universities, and the quality of education may fall in the host country. However, few (if any) studies have tried to look at the effects of such policies which are conducted in destination countries on the choice of location made by a student in sending countries. As in Van Bouwel and Veugelers (2013), we use different measures as quality indicators: the number of universities a country has in the top 100 of the Shanghai ranking and the quality of public services in $\mathrm{HE}$ (teaching and research). However, other characteristics which describe the immigration climate and the accessibility to public facilities will also be added to test the "attractiveness" of HEIs in the host country.

Our purpose here is also to determine how developing countries can "push" or discourage exit by migrants who are skilled (students). On the sending country side, quality considerations (teaching, research, employability) or improvement in human capital through internationalization of $\mathrm{HE}$ can be taken into consideration. For example, relatively few institutions in developing countries provide doctoral education. Therefore, the driving force for student mobility appears to be the lack of educational opportunities in the home country at graduate level. In our specific case, it means that HE supply is not sufficient to meet demand in the origin country: moving abroad to get a better education may be the best solution to incomplete education markets (Bansak et al., $2015)^{5}$. More interestingly, socio-demographic characteristics of home countries are introduced in our study. Indeed, a "youth bulge" in the home country may increase the population of young adults, the group most likely to migrate in search of better opportunities.

The recent literature puts evidence that economic conditions (income, unemployment rate, tax burden, skills shortage) matter more in destination countries than in sending countries, implying that they are bigger pull factors than push factors (Bansak et al., 2015). However, existing studies

\footnotetext{
${ }^{5}$ Relying on micro-data of 2,485 students from four countries (China, India, Indonesia, Taiwan), Mazzarol and Soutar (2002) claim that the difficult to gain entry at home and course not available at home appear to be the main reasons pushing these students studying abroad.
} 
show mixed results on these economic aspects. For example, the level of GDP per capita (a proxy of development) in the home country has been found negative in explaining outflows in some empirical studies (Clark et al., 2007; Hatton and Williamson, 2005; Pedersen et al., 2008). But unlike the negative prediction, some others have found positive or ambiguous effect (Grogger and Hanson, 2011; Mayda, 2010). As average incomes rise, fewer people are migrating because the country's economy is better off (negative correlation); but it may happen that more people can afford to migrate, thereby developing emigration flows (positive correlation). The present study will address this issue in the specific flows of student migrants.

Lastly, policies or restrictions that discourage out bound students can also be viewed from the sending country side. Emigration may affect the sending country (especially when migrants are skilled), and concern that these effects are negative is the main reason why some countries impose restrictions on emigration (especially in developing ones). For some authors, the so-called "brain drain" (loss in highly-skilled labor force, loss in social welfare, etc. which occur within the origin country) is however counter-balanced by a "brain gain", that is: the sending country benefits if emigrants return after acquiring skills abroad or if the possibility of emigrating causes residents to acquire more skills as the expected return to education increases (Docquier and Sekkat, 2006). In this line of argument, we expect here that international students coming in the sending country bring positive externalities in terms of knowledge, learning capacity and human capital formation.

To deal with all the monodic factors underlying institutions, beliefs or perceptions in sending and receiving countries, we use the Institutional Profiles Database (IPD) which has been a collaborative result from the French Development Agency (AFD) and the Directorate General of the Treasury (DG Trésor). The IPD provides an original measure of countries' institutional characteristics through composite indicators built from perception data ${ }^{6}$. These indicators are made available for academic research purposes and more specifically to explore the relationship between institutions and development. Other macroeconomic data are mainly downloaded from the World Bank database (World Development Indicators) and from Eurostat. Table 1 reports our different variables of interest and their source. Some summary statics are presented in Appendix C.

\section{Methodology}

\subsection{Theoretical background}

The present study applies the Random Utility Maximization (RUM) model of migration (Beine et al., 2011, 2016; Bertoli and Fernández-Huertas Moraga, 2013, 2015 among others) to the context of international mobility of students. The main assumption underlying this research framework is the existence of multilateral resistance to migration.

Let's start with the migration decision of a student $k$ in country $i \in O$ to country $j \in D$

$$
U_{k i j}=a_{i j}-c_{i j}+\epsilon_{k i j}
$$

where $i=1,2, \ldots O$ is a set of origin countries and $j=1,2, \ldots D$ is a set of destination countries. Variable $a_{i j}$ implies a deterministic component of utility while $c_{i j}$ includes specific costs of moving from $i$ to $j$, and $\epsilon_{k i j}$ is a student-specific stochastic term. It is assumed to follow an independent and identically distributed extreme value type 1 distribution (iid EVT-1).

Let $p_{i j}$ be the probability that student $k$ chooses country $j$ instead of staying at home or an alternative country $l \in D$. If the deterministic component does not vary with origin country $i$, this probability can be expressed as in Beine et al. (2013):

$$
\begin{aligned}
p_{i j} & =\operatorname{Pr}\left\{U_{k i j}=\max _{l \in D} U_{k i l}\right\} \\
& =\frac{e^{a_{i}-c_{i j}}}{\sum_{l \in D} e^{a_{l t}-c_{i l t}}} \\
& =\frac{S_{i j}}{S_{i}}
\end{aligned}
$$

${ }^{6}$ Source: http://www.cepii.fr/institutions/EN/ipd.asp 
Table 1: List of variables

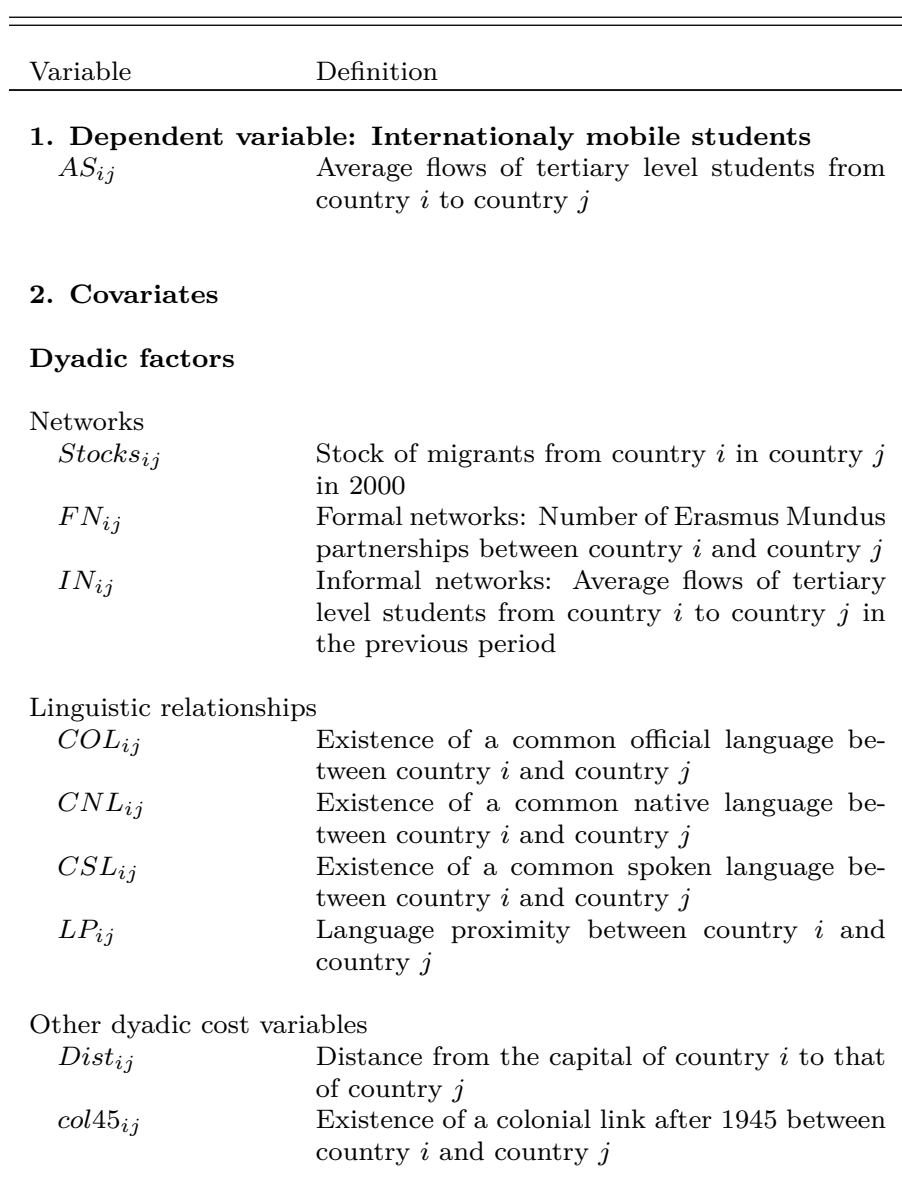

Source

Available years

Dependent variable: Internationaly mobile students

$A S_{i j} \quad$ Average flows of tertiary level students from

UNESCO

$2004-2013$

\section{Covariate}

Dyadic factors

OECD

2000

Authors construction

UNESCO

2004-2013

1999-2003
CEPII
CEPII
CEPII
CEPII

CEPII

CEPII

\section{Monodic factors}

Push factors (home countries)

Economic and socio-demographic factors

$\begin{array}{ll}G D P c a p_{i} & \text { GDP per capita in } 2004 \\ Y u_{i} & \text { Unemployment, youth total (\% of total labor } \\ & \text { force ages 15-24) } \\ \text { Enrol }_{i} & \text { Enrollments in tertiary education } \\ A N_{i} & \text { Internationally mobile students coming from } \\ & \text { host countries }\end{array}$

World DataBank

ILO database

2004

World DataBank UNESCO

Political environment and institutional factors

A2031 $i \quad$ Internal conflicts

$A 8020_{i} \quad$ Internal tensions caused by neighboring countries

$A 8001_{i} \quad$ Freedom to leave the country

$A 5033_{i}$

International/regional integration

PD - CEPII

2004-2013

IPD - CEPII

2012

IPD - CEPII 2012

Quality of $H E$

$D 9002_{i}$

Quality of public higher education and research services

$D 5010_{i} \quad$ Adaptation of the higher education system to business needs

Beliefs of young people

$A 5100_{i} \quad$ Prospects for young people

$A 8001_{i} \quad$ Irregularities in obtaining university

$D 9040_{i} \quad$ Importance of merit to upward social mobility

$D 9061_{i} \quad$ Reluctance of firms to hire university graduates

$\begin{array}{lc}\text { IPD - CEPII } & 2012 \\ \text { IPD - CEPII } & 2012 \\ \text { IPD - CEPII } & 2012 \\ & \\ \text { IPD - CEPII } & 2012 \\ & \\ & \\ \text { IPD - CEPII } & 2012 \\ \text { IPD - CEPII } & 2012 \\ \text { IPD - CEPII } & 2012 \\ \text { IPD - CEPII } & 2012\end{array}$


Table 1: List of variables (continued)

\begin{tabular}{|c|c|c|c|}
\hline Variable & Definition & Source & Available years \\
\hline \multicolumn{4}{|c|}{ Pull factors (host countries) } \\
\hline \multicolumn{4}{|c|}{ Economic and socio-demographic factors } \\
\hline$P L I_{j}$ & $\begin{array}{l}\text { Price Level Index, actual individual consumption, } \\
\text { by using purchasing power parity (PPP) }\end{array}$ & Eurostat & 2004-2013 \\
\hline Enrol $_{j}$ & Enrollments in tertiary education & World DataBank & 2004-2013 \\
\hline genderratio $_{j}$ & $\begin{array}{l}\text { Female / male ratio of enrollments in higher } \\
\text { education }\end{array}$ & UNESCO & 2004-2013 \\
\hline \multicolumn{4}{|c|}{ 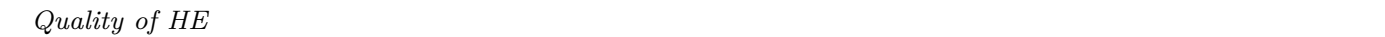 } \\
\hline$D 9002_{j}$ & $\begin{array}{l}\text { Quality of public higher education and re- } \\
\text { search services }\end{array}$ & IPD - CEPII & 2012 \\
\hline ranking $_{j}$ & Number of universities in ShangHai Top100 & ARWU & $2004-2013$ \\
\hline$D 5010_{j}$ & $\begin{array}{l}\text { Adaptation of the higher education system to } \\
\text { business needs }\end{array}$ & IPD - CEPII & 2012 \\
\hline \multicolumn{4}{|c|}{ Socio-economic environment } \\
\hline$D 9003_{j}$ & $\begin{array}{l}\text { Quality of public services (provided by the } \\
\text { public sector) in relation to basic healthcare }\end{array}$ & IPD - CEPII & 2012 \\
\hline migrants $_{j}$ & Total stock of migrants, $\%$ of population & World DataBank & 2010 \\
\hline
\end{tabular}

where $S_{i j}$ represents the number of students from $i$ moving to $j$, and $S_{i}$ the total number of students residing in $i$.

Hence, if we take the ratio between the number of students moving from $i$ to $j$ and that of stayers, it can be given by:

$$
\frac{S_{i j}}{S_{i i}}=\frac{e^{a_{j}-c_{i j}}}{e^{a_{i}}}
$$

from where the number of students moving abroad can be expressed as:

$$
S_{i j}=\frac{e^{a_{j}-c_{i j}}}{e^{a_{i}}} S_{i i}
$$

where $a_{j}$ can be consider as the specific attractiveness of destination country $j$ or pull factors. On the other hand, $a_{i}$ captures specific characteristics of the home country $i$ pushing students to study abroad or push factors.

\subsection{Econometric strategy}

Based on Equation (4), we first consider a benchmark model where the average number of students from country $i$ studying in country $j$ can be expressed in log as:

$$
A S_{i j}=\alpha+\alpha_{i}+\alpha_{j}+\beta . c_{i j}+\gamma \cdot N_{i j}+\zeta . l_{i j}+\epsilon_{i j}
$$

where $c_{i j}$ captures variable costs depending on dyadic factors between origin country $i$ and host country $j$ such as physical distance $d_{i j}$ and colonial link col $45_{i j}$. We add here two other kinds of dyadic factors: networks $\left(N_{i j}\right)$ and shared language $\left(l_{i j}\right)$. All specific characteristics of the home and host countries are respectively captured by $\alpha_{i}$ and $\alpha_{j}$ while $\epsilon_{i j}$ is an error term.

The main purpose of Equation (5) is to focus on the role of dyadic factors. More precisely, we attempt different measures of network and those of linguistic relationship between the home and the host countries. Otherwise, including the origin dummies allows us to control for origin-specific factors while adding the destination dummies take into account destination-specific factors. The inclusion of dummies makes the estimates consistent with the aforementioned RUM model (Ortega and Peri, 2013; Bertoli and Fernández-Huertas Moraga, 2015).

However, to capture both push and pull factors, we need to replace the origin and destination dummies in distinctive specifications. We first investigate the role of push factors and Regression (5) can be rewritten as:

$$
A S_{i j}=\alpha+\alpha_{j}+\beta . c_{i j}+\gamma \cdot N_{i j}+\zeta . l_{i j}+\theta . \Omega_{i}+\epsilon_{i j}
$$

where $\alpha_{i}$ is replaced by different push factors $\Omega_{i}$ and $\alpha_{j}$ is kept to capture specific fixed effects of the host country $j$. These push factors can be divided into four groups 
(i) Economic and socio-demographic factors

(ii) Political environment and institutional factors

(iii) Quality of HE

(iv) Beliefs of young people

Second, we examine how attractiveness of the host country (pull factors) affects the international mobility in HE by using the following equation:

$$
A S_{i j}=\alpha+\alpha_{i}+\beta \times c_{i j}+\gamma \cdot N_{i j}+\zeta . l_{i j}+\theta . \Omega_{j}+\epsilon_{i j}
$$

where all specific fixed effects of the sending country $i$ are captured by $\alpha_{i}$ while $\Omega_{j}$ includes different pull factors.

In a last step, both push and pull factors are combined to shed light on the interactions between specific determinants of attractiveness and exit. We rely on the following equation:

$$
A S_{i j}=\alpha+\beta . c_{i j}+\gamma \cdot N_{i j}+\zeta . l_{i j}+\theta_{1} . \Omega_{i}+\theta_{2} . \Omega_{j}+\epsilon_{i j}
$$

where $\alpha_{i}$ is replaced by different home specific factors $\Omega_{i}$ and $\alpha_{j}$ is replaced by different destination specific factors $\Omega_{j}$.

Equations (5) to (8) can be estimated by the OLS method. However, owing to the presence of zero flows (representing 14\% of our sample), covariates can be correlated with the error terms, which makes the OLS model inconsistent. To deal with this concern, the two-stage method à la Heckman as in Beine et al. (2011) and the Poisson Pseudo-Maximum Likelihood Estimator (PPML) as in Beine et al. (2014) can be relevant. In this research, we rely on the PPML estimator which has been developed by Silva and Tenreyro (2006). This method allows us to deal with two problems associated with the log-linearization of observed values: (i) the existence of heteroskedasticity, which leads to inconsistent estimates and (ii) the presence of zero flows as aforementioned.

Along the estimation process, the dependent variable is the average flow of migrant students from country $i$ to country $j$ over the period 2004 to 2013. We do not estimate neither the pool nor annual data for two reasons. First, according to Beine et al. (2014), some dyadic factors like linguistic, colonial links and Euclidean distance are constant overtime and can be included in bilateral specific effects in pooling data. Second, estimating annual migrant students separately may not control for sudden shocks and thus lead to biased estimated coefficients.

\section{Main findings}

\subsection{Role of dyadic factors}

This subsection aims at investigating the role of dyadic factors in determining international student mobility, keeping dummies for the fixed effects of home and host countries. In complement to the mobility costs which are commonly used in gravity empirics, two other kinds of dyadic resistance are explored in this purpose.

\section{Role of Networks}

Based on Equation (5), we expect to find evidence on the impacts of three kinds of networking on outflow of students : (i) Average migrant students in the past considered as "informal network", (ii) Average numbers of EMA2 partnerships between home and host countries as a proxy for "formal network", and (iii) Stock of migrants in 2000, defined as a general measure of network effects in numerous empirical studies. The associated estimates are displayed in Table 2. Each measure of networks is studied separately in alternative models from 1 to 3 and to focus on their role, we assume for the moment that linguistic links are proxied by Common official language (COL).

Table 2 depicts robust and positive effects of networks: whatever the measure under consideration, networks influence student mobility. This is consistent with predictions, especially when it concerns developing countries. Pedersen et al. (2008) for example, found that networks matter the most for immigrants coming from poor origin countries. 
Table 2: Determinants of HE mobility: Role of Networks

\begin{tabular}{|c|c|c|c|}
\hline Dependent variable & $\begin{array}{c}\text { Model } 1 \\
A S_{i j}\end{array}$ & $\begin{array}{c}\text { Model } 2 \\
A S_{i j}\end{array}$ & $\begin{array}{c}\text { Model } 3 \\
A S_{i j}\end{array}$ \\
\hline \multicolumn{4}{|l|}{ Network } \\
\hline Stock of migrant (in log) & $\begin{array}{c}0.238^{* * *} \\
(0.041)\end{array}$ & & \\
\hline Average migrant students in the previous period (in log) & & $\begin{array}{c}0.805^{* * *} \\
(0.028)\end{array}$ & \\
\hline Average number of EM partnerships (in log) & & & $\begin{array}{c}0.469^{* *} \\
(0.150)\end{array}$ \\
\hline Distance (in log) & $\begin{array}{c}-1.691^{* * *} \\
(0.277)\end{array}$ & $\begin{array}{c}-0.653^{* * *} \\
(0.169)\end{array}$ & $\begin{array}{c}-2.163^{* * *} \\
(0.296)\end{array}$ \\
\hline Post 1945 colonial link & $\begin{array}{c}0.905^{* * *} \\
(0.199)\end{array}$ & $\begin{array}{l}-0.015 \\
(0.091)\end{array}$ & $\begin{array}{c}1.035^{* * *} \\
(0.203)\end{array}$ \\
\hline \multicolumn{4}{|l|}{ Linguistic link } \\
\hline Common official language & $\begin{array}{c}1.428^{* * *} \\
(0.210)\end{array}$ & $\begin{array}{c}0.504^{* * *} \\
(0.096)\end{array}$ & $\begin{array}{c}1.684^{* * *} \\
(0.190)\end{array}$ \\
\hline Constant & $\begin{array}{c}19.821^{* * *} \\
(2.753)\end{array}$ & $\begin{array}{c}6.890^{* * *} \\
(1.653)\end{array}$ & $\begin{array}{c}25.103^{* * *} \\
(2.778)\end{array}$ \\
\hline Origin fixed effects & Yes & Yes & Yes \\
\hline Destination fixed effects & Yes & Yes & Yes \\
\hline Number of origin countries & 89 & 89 & 89 \\
\hline Number of destination countries & 30 & 30 & 30 \\
\hline Observations & 2,670 & 2,670 & 2,670 \\
\hline R-squared & 0.907 & 0.987 & 0.886 \\
\hline Pseudo log-likelihood & -146486 & -45593 & -165841 \\
\hline
\end{tabular}

Clustered and Robust standard errors in parentheses. Significant: ${ }^{* * *} \mathrm{p}<0.001,{ }^{* *} \mathrm{p}<0.01,{ }^{*} \mathrm{p}<0.05,+\mathrm{p}<0.1$

Specification 1 introduces the same dyadic factors as in Beine et al. (2014). Compared to their findings, the elasticity of Stock of migrantsis found to be lower while that of other dyadic factors is higher in our study. One possible reason is that our sample only contains students from LMIs while Beine et al. (2014) consider both students from developing and developed countries. Consequently, the "resistance" to migration is stronger in our country sample. However, we find divergent contribution of networking. Stock of migrants appears to have the smallest impact, with an elasticity of 0.238 (Model 1) whereas Average migrant students in the previous period has the highest effect. From a qualitative point of view, including this variable in the estimator reports very high R-squared (about 99\%) while ignoring it displays a lower explanation level of the model (i.e. 91\% in Specification 1 and 89\% in Specification 3). Consequently, each 1\% increase in HE mobility during the period 1999-2003 explains an average growth of 0.8\% between 2004-2013. Surprisingly, formal networks captured by the number of Erasmus Mundus partnerships between home and host countries are less important than the informal ones.

These divergent impacts of networking can be explained as follows. On the one hand, to decide on studying abroad, potential migrant students may first search feedback from former migrant students, then available information from formal networks (i.e. HEIs), and lastly from immigrants in the destination country. It is possible that such feedback contains decisive information on education quality, integration and administrative facilities, quality of life, etc. On the other hand, it is possible that the contribution of formal networks is partly included in other variables like colonial link or COL for which the associated coefficient is much higher in Model 3. Hence, it seems that two countries sharing either the same official language or a common history also exhibit a high number of partnerships.

As expected, the results on Distance are in line with theoretical predictions (see for example Rodriguez Gonzalez et al., 2011; Beine et al., 2014; Appelt et al., 2015). But similar to postcolonial link, the associated coefficient is of less magnitude in informal student networks. In fact, Grogger and Hanson (2011) talk about the "great circle" of distance to describe how both effects 
of network and physical distance act together. When the coefficients associated to each variable are aggregated, this "great circle" in informal network lowers the cost of migrating and stimulates student mobility $(0.805-0.653=0.152$ in Model 2$)$ while it still discourages outflows in the two other networks (respectively -1.453 and -1.694 in Models 1 and 3 ).

Other dyadic factors were investigated in order to proxy commercial links between countries: regional trade agreements, preferential treatment of imports coming from former colonies or some specific developing countries. The results appear to be insignificant in explaining student mobility. Therefore, in order to keep tractability of our empirical investigation and to shorten our tables, we leave them aside.

According to Table 2, sharing the same official language increases the number of internationally mobile students by at least $65.5 \% .^{7}$ However, using a sole measure of common language might underestimate this effect. ${ }^{8}$ As noted Bertoli and Fernández-Huertas Moraga $(2013$, 2015), potential migrants face multilateral resistance and in our case, linguistic skills are likely to be an important factor. Hence, in order to have a fresher eye on the role of linguistic relations, different indicators will be taken into account in what follows.

\section{Role of linguistic skills}

We explore here four indicators of linguistic relationships (COL, CSL, CNL, and LP) as shown in Melitz and Toubal (2014, 2016). Estimation results using Equation (5) and relying on the PPML method are reported in Table 3. Since Stock of migrants is less important, only Average migrant students in the previous period and Average number of EM partnerships are kept afterwards in order to explore the resistance of informal versus formal networks. From columns (1) to (4), informal network is focused while in the last four columns, this variable is replaced by formal network. For both networking, each indicator of linguistic relationship is considered separately: COL in Model 1, CSL in Model 2, and CNL in Model 3. In Model 4, the three indicators are gathered together before introducing language proximity in Model 5.

Whatever the related network, COL, CSL and $C N L$ are all significant at $0.1 \%$ level when they are alternatively controlled for. However, $C N L$ and $C S L$ appear to have a stronger impact on the flows of student mobility. In informal networks for example, sharing $C S L(C N L)$ with an European host country increases the number of mobility students from the related sending country by $232 \%(249 \%)$ and when these variables are all introduced in the estimation (Column 4), only $C S L$ remains significant. Similar results occur when $L P$ is introduced. Since neither $C O L$ nor $C N L$ is significant, their role is probably absorbed by $C S L$, implying the importance of communication facility over influence of ethnicity and mutual trust in the higher education's migration. All in all, these findings support our aforementioned intuition that using the sole $C O L$ may underestimate the role of linguistic skills.

When formal network is considered separately, the coefficients of common language become at least three times higher than those associated with informal network. It is possible that European countries use the EMA2 programme to apply indirectly "qualitative" selection criteria (therefore immigration policies) on skilled migrants. Coniglio and Kondoh (2015) for example, argue that the EU uses restrictive requirements in language skills to limit the number of immigrants from non-EU countries. It follows that only students with sufficient linguistic levels are selected by EMA2 partners in the sending and the destination countries, enabling linguistic resistance to become stronger in the formal network than in the informal one. When all linguistic indicators are gathered, CSL remains the most important indicator.

Interestingly, the coefficients of Distance and Colonial link associated with formal networks are found to be much higher than those related to informal networks. Historical ties are highly significant in the former network and this may also reflect an immigration policy, that is: inflows are selected through admission preferences to students of former colonies. These findings tend to support our above-mentioned intuitions. On the one hand, the low contribution of institutional network may be possibly absorbed by colonial and linguistic relations. On the other hand, feedback

\footnotetext{
${ }^{7}$ The coefficient of COL is the lowest in Specification 2. The associated impact is computed by: exp(0.504)$1=0.655$, that is $65.5 \%$.

${ }^{8}$ In the case of bilateral trade, using a sole linguistic relationship only explains one fifth of the total impact (Melitz and Toubal, 2014).
} 


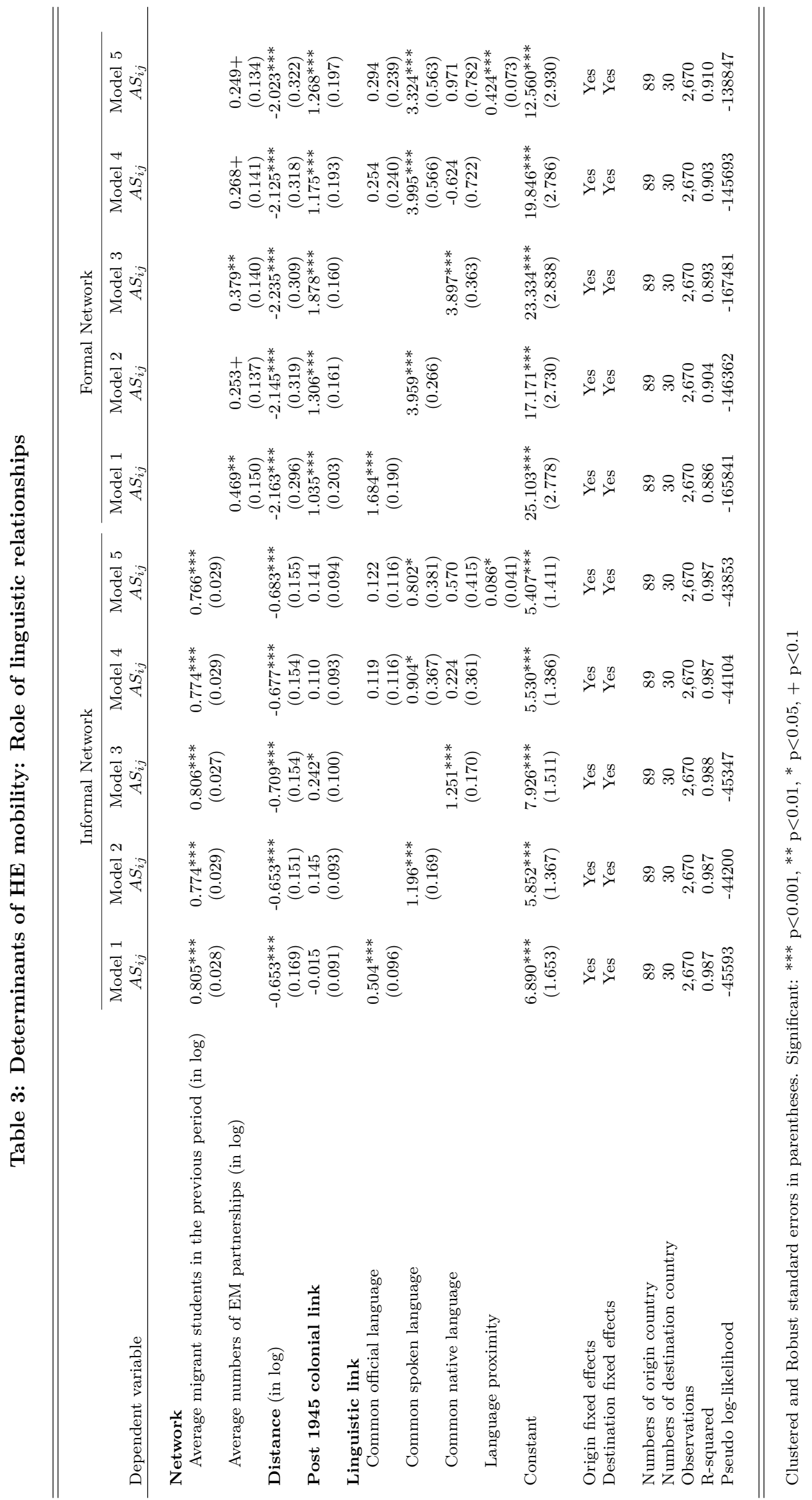


from former migrant students is so important that distance is less costly and colonial link becomes insignificant in informal networks.

\section{Discussion}

Our findings indicate that social interactions through networking matter, and linguistic links (which are other ties connecting individuals) also matter and may even hide selective criteria to entries. In summary, CSL appears to be the most important linguistic resistance to international mobility in HE while the most important network effect comes from informal interactions.

Our analysis about the role of dyadic factors makes two important contributions to the literature. Firstly, we show how important it is to consider different linguistic indicators (Melitz and Toubal, 2014, 2016). Using only one of them can lead to an underestimated value and thus make inconsistent the interpretation.

The second important contribution is the inclusion of different measures of networking while most studies on the topic consider only Stock of migrants (Beine et al., 2011, 2014; Bertoli and Fernández-Huertas Moraga, 2013 among others). In our paper however, once other indicators of networking are controlled for, the role of Stock of migrants becomes even insignificant ${ }^{9}$. These findings can be explained as follows.

First, former migrant students are the main sources of information (on living conditions, education quality, friendly administration, etc.), which helps to shrink "sunk costs" for potential migrant students. Moreover, such information is likely to be more relevant than that supplied by countryman (from stock of migrants) or formal partnerships. In a certain sense, our results seem to be consistent with Beine et al. (2014) who also show a higher impact of skilled migrants on the flow of international students compared to general ones.

Second, the small contribution of Stock of migrants and Institutional partnerships can be partly absorbed by other covariates like Colonial link or common languages. In addition, our finding on the role of formal network (captured here by the Number of EM partnerships between EU and non-EU countries) is in the same spirit that Shields (2013) who underlines the positive impact of international governmental organization membership on the international mobility of students.

\subsection{Role of Monodic factors}

The aforementioned analysis does not control for countries characteristics. Yet, taking into account country specific factors are important in terms of policy implications. On the home side, it helps us ti understand why students do not desire to pursuing their study at home. On the host side, it will suggest some policy-relevant outcomes in terms of attractiveness. To tackle these issues in what follows, only CSL is taken to measure linguistic resistance and Average migrant students in the previous period are estimated separately to shed light on the impact of country specific factors on informal networks alternatively to aggregated networks.

\subsubsection{Push factors}

Table 4 reports the role of monodic push factors in the mobility of HE. Estimates relies on the PPML method basing on Equation (6). Both formal and informal networks are gathered in the first estimations. Economic and socio-demographic factors are explored in Model 1 and then institutional profiles provided by the IPD will be introduced to highlight qualitative aspects in Model 2. In Model 3, informal network is considered separately in a comparative perspective.

Looking at Model 1, our empirical results evidence a qualitatively strong impact of economic and socio-demographic factors in sending countries. Consistent with theoretical predictions, the initial level of GDP per capita, which is an indicator of their development level, appears to be negative and statistically significant at $0.1 \%$ level. The associated sign suggests that a substitution effect prevails: as the home country gets richer, students will prefer to stay at home and the number of them moving abroad will decrease. Conversely, poorer countries tend to have higher student outflows because educational opportunities are more limited there. As aforementioned in Section

\footnotetext{
${ }^{9}$ Estimated results are available upon request.
} 
Table 4: Determinant of HE mobility: Role of home monodic factors

\begin{tabular}{|c|c|c|c|}
\hline \multirow[b]{2}{*}{ Dependent variable } & \multicolumn{2}{|c|}{ Informal \& formal networks } & \multirow{2}{*}{$\begin{array}{c}\text { Informal network } \\
\text { Model } 3 \\
A S_{i j} \\
\end{array}$} \\
\hline & $\begin{array}{c}\text { Model } 1 \\
A S_{i j}\end{array}$ & $\begin{array}{c}\text { Model } 2 \\
A S_{i j} \\
\end{array}$ & \\
\hline \multicolumn{4}{|l|}{ Dyadic factors } \\
\hline \multicolumn{4}{|l|}{ Network (in log) } \\
\hline Average migrant students in the previous period & $\begin{array}{c}0.843^{* * *} \\
(0.024)\end{array}$ & $\begin{array}{c}0.831^{* * *} \\
(0.024)\end{array}$ & $\begin{array}{c}0.848^{* * *} \\
(0.024)\end{array}$ \\
\hline Average numbers of EM partnerships & $\begin{array}{c}0.107^{* *} \\
(0.040)\end{array}$ & $\begin{array}{c}0.112^{* *} \\
(0.037)\end{array}$ & \\
\hline Distance (in log) & $\begin{array}{c}-0.184^{* * *} \\
(0.051)\end{array}$ & $\begin{array}{c}-0.138^{*} \\
(0.056)\end{array}$ & $\begin{array}{c}-0.151^{* *} \\
(0.052)\end{array}$ \\
\hline Post 1945 colonial link & $\begin{array}{l}-0.018 \\
(0.096)\end{array}$ & $\begin{array}{c}0.004 \\
(0.089)\end{array}$ & $\begin{array}{l}-0.008 \\
(0.091)\end{array}$ \\
\hline Common spoken language & $\begin{array}{c}0.511^{* *} \\
(0.179)\end{array}$ & $\begin{array}{c}0.626^{* * *} \\
(0.170)\end{array}$ & $\begin{array}{c}0.581^{* * *} \\
(0.158)\end{array}$ \\
\hline \multicolumn{4}{|l|}{ Monodic Push factors } \\
\hline GDP per capita in 2004 (in log) & $\begin{array}{c}-0.165^{* * *} \\
(0.046)\end{array}$ & $\begin{array}{c}-0.188^{* * *} \\
(0.047)\end{array}$ & $\begin{array}{c}-0.165^{* * *} \\
(0.048)\end{array}$ \\
\hline Young unemployment ( $\%$ of total labor force ages $15-24$ ) & $\begin{array}{c}-0.016^{* * *} \\
(0.004)\end{array}$ & $\begin{array}{c}-0.010^{*} \\
(0.004)\end{array}$ & $\begin{array}{c}-0.007+ \\
(0.004)\end{array}$ \\
\hline Average Enrollment in tertiary education (in log) & $\begin{array}{c}0.197^{* * *} \\
(0.029)\end{array}$ & $\begin{array}{c}0.208^{* * *} \\
(0.032)\end{array}$ & $\begin{array}{c}0.239 * * * \\
(0.027)\end{array}$ \\
\hline Internationally mobile students coming from host countries & $\begin{array}{c}-0.033^{* *} \\
(0.013)\end{array}$ & $\begin{array}{c}-0.022 \\
(0.014)\end{array}$ & $\begin{array}{c}-0.035^{* *} \\
(0.013)\end{array}$ \\
\hline \multicolumn{4}{|l|}{ Political environment and institutional factors } \\
\hline Internal conflicts & & $\begin{array}{c}-0.118^{* *} \\
(0.040)\end{array}$ & $\begin{array}{c}-0.083^{*} \\
(0.041)\end{array}$ \\
\hline Internal tensions caused by neighboring countries & & $\begin{array}{l}-0.029 \\
(0.029)\end{array}$ & $\begin{array}{l}-0.032 \\
(0.026)\end{array}$ \\
\hline Freedom to leave the country & & $\begin{array}{l}-0.048 \\
(0.074)\end{array}$ & $\begin{array}{l}-0.087 \\
(0.074)\end{array}$ \\
\hline International/regional integration & & $\begin{array}{c}0.030 \\
(0.043)\end{array}$ & $\begin{array}{c}0.038 \\
(0.039)\end{array}$ \\
\hline \multicolumn{4}{|l|}{ Quality of $H E$} \\
\hline Quality of public HE services & & $\begin{array}{l}0.081+ \\
(0.041)\end{array}$ & $\begin{array}{l}0.069+ \\
(0.041)\end{array}$ \\
\hline Adaptation of $\mathrm{HE}$ to business needs & & $\begin{array}{l}-0.079 \\
(0.049)\end{array}$ & $\begin{array}{l}-0.048 \\
(0.049)\end{array}$ \\
\hline \multicolumn{4}{|l|}{ Students' beliefs } \\
\hline Prospect for young people & & $\begin{array}{l}0.081+ \\
(0.042)\end{array}$ & $\begin{array}{c}0.091^{*} \\
(0.041)\end{array}$ \\
\hline Irregularities in obtaining university degrees & & $\begin{array}{c}0.154^{* * *} \\
(0.037)\end{array}$ & $\begin{array}{c}0.157^{* * *} * \\
(0.036)\end{array}$ \\
\hline Importance of merit to upward social mobility & & $\begin{array}{c}0.094^{*} \\
(0.041)\end{array}$ & $\begin{array}{c}0.112^{* *} \\
(0.042)\end{array}$ \\
\hline Reluctance of firms to hire university graduates & & $\begin{array}{c}0.001 \\
(0.032)\end{array}$ & $\begin{array}{c}-0.033 \\
(0.030)\end{array}$ \\
\hline Constant & $\begin{array}{c}4.495^{* * *} \\
(0.595)\end{array}$ & $\begin{array}{c}3.688^{* * *} \\
(0.833)\end{array}$ & $\begin{array}{c}3.627^{* * *} \\
(0.778)\end{array}$ \\
\hline Origin fixed effects & No & No & No \\
\hline Destination fixed effects & Yes & Yes & Yes \\
\hline Number of origin countries & 81 & 79 & 79 \\
\hline Number of destination countries & 30 & 30 & 30 \\
\hline Observations & 2,430 & 2,370 & 2,370 \\
\hline R-squared & 0.964 & 0.971 & 0.972 \\
\hline Pseudo log-likelihood & -65098 & -59488 & -61162 \\
\hline
\end{tabular}

Clustered and Robust standard errors in parentheses. $\quad * * * \mathrm{p}<0.001,{ }^{* *} \mathrm{p}<0.01,{ }^{*} \mathrm{p}<0.05,+\mathrm{p}<0.1$

Note: The number of observations declines due to missing data on institutional indicators (Gambia and Kyrgyz Republic) and enrollments (Gabon, Libya, Haiti,Nicaragua, Sierra Leone, Somalia, Turkmenistan and Zambia) 
2, the impact of this factor is shown to be contradictory in determining emigration. In the case of Asian students moving to the UK, a positive impact has been found by (Naidoo, 2007). By contrast, Vogtle and Windzio (2016) shows no evidence of student mobility from poor to richer countries. In our paper, a negative impact of GDP per capita on student mobility to Europe means that it is not necessarily a push factor.

Surprisingly, a high unemployment rate of young people hinders international mobility. In contrast to the first economic variable, this result suggests an income or subsistence effect in mobility decision. When the young individual is affected by unemployment, he is more likely to migrate as the probability of finding a job at home decreases. However, this push factor matters more for some groups of migrants than others: especially for work-based migrants. But for young students, the opportunity to get a better education may be dampened because they do not have enough resource to finance their study abroad. Or alternatively, the opportunity cost of education is higher. In sum, unemployment describes a joint effect of income and investment perspectives: young individuals will have to look for a job first. In this sense, the investment decision in human capital will be given up.

Interestingly, Enrollment in tertiary education is found to be statistically significant at $0.1 \%$ level and the associated coefficient is positive: an increase of $10 \%$ in the number of enrolled students in the home country leads to a growth of $2 \%$ in outflows. Hence, the number of enrollments in tertiary education underlies a home cohort or a "market size" effect in international mobility; i.e. the potential capacity to send students abroad to improve their human capital. On the opposite, the number of Internationally mobile students coming from host countries negatively affects the outflow of students, although the impact is low both qualitatively and quantitatively. This variable may bring evidence of a circular effect in bilateral flows of students: a higher number of incoming students improves learning capacity in the sending country, discouraging domestic students to move abroad. According to Docquier and Sekkat (2006), the presence of network effects with temporary mobility creates the ability of brain exchange or "brain circulation". From a brain gain perspective, entries of students coming from abroad (here, from Europe) enhances the human capital of all students at origin.

When the subgroup of institutional factors and perceptions in the home countries are added in Model 2, the estimated coefficients associated with economic factors remain robust but the circular effect becomes insignificant. Unemployment becomes less significant for two reasons. First, the investment decision on education overwhelms the income constraint when other factors are taken into consideration. Second, this investment decision abroad can be partly supported by scholarships offered in formal partnerships. Turning first to the set of political institutions, security and order, Internal conflicts are found to be negative and statistically significant at $5 \%$. It is likely that the more a home country experiences intensive internal conflicts, the more it closes its boundaries and prevents any emigration. In addition, since Internal tensions caused by neighboring countries, Freedom to leave the country, and International/regional integration occur to have insignificant impacts, it is possible that Internal conflicts are the most important institutional factor that describes political environment and absorb impacts of the three other variables. Obviously, when the former is removed from the estimation, Freedom to leave the country turns out to become significant while impacts of the two other variables remain insignificant. ${ }^{10}$

Moving on to the role of Quality considerations, it appears that no variable is significant at $5 \%$ level: either because they do not influence education decision, or because their impacts are absorbed by other factors. In fact, whether to move abroad or not is a decision made in response to sequential arbitrage where the quality dimension seems to be considered after economic, social and political aspects. In addition, we explore the role of individual beliefs in the home country. Reluctance of firms to hire university graduates is insignificant while the other three variables are shown to affect positively outflows. In countries where Irregularities in obtaining university degrees (fraud, purchases of diplomas) are high, students believe that HEIs are corrupted and are pushed abroad. Likewise, if the Merit to upward social mobility is considered important, students are more motivated to study abroad. In other words, beliefs or individual perception on the prevalence of corruption, the fairness of public institutions may push students into becoming

\footnotetext{
${ }^{10}$ Estimate results are available upon request.
} 
mobile internationally.

In Model 3, informal networks are investigated separately. Some divergent results compared to those of Model 2 appear. Looking first at the dyadic factors, the role of Distance increases in informal networks while the coefficient associated to language skill decreases. The reason is that the choice of location is constrained by the EMA2 programmes whereas informal networks allow students to move by themselves and to choose freely where to go. Hence, it is likely that institutional partnerships through EMA2 programmes help to reduce distance in HE mobility, but at the expense of stricter language requirements.

When we look at push factors in the specific case of informal networks, the circular effect becomes significant. In other words, hosting international students in the origin country, be it in the framework of formal partnerships or not, encourages students to stay. Besides that, impacts of Students beliefs are also dependent upon the associated networking. Compared to Model 2, Prospect of young people is found to have a significant positive impact on informal network. It implies that the more young people is outward oriented, the more they want to pursue their study abroad. It is possible that in a country where young people are open to the rest of the word, they search for the simplest way to study overseas. In contrast, applying for EMA2 programmes requires stricter conditions that discourage their motivation to study abroad.

\subsubsection{Pull factors}

By capturing the role of destination specific characteristics, Table 5 depicts monodic pull factors when we consider home fixed effects. Based on the PPML method formalized by Equation (7), we conduct the same empirical exercise. Models 1 and 2 integrate both formal and informal networks in investigating successively economic and socio-demographic variables, then institutional aspects. In Model 3, we only consider informal network with all monodic pull factors.

Compared with previous tables, dyadic factors have a different effect at destination. On the one hand, Post colonial link here has a positive and significant effect at $1 \%$. Whereas historical relations do not affect student exit from the home perspective, they strongly affect the choice of the host country. On the other hand, formal networks have no significant effect. This means that the different EMA2 partnerships essentially encourage students from the LMI countries to study abroad without determining where they will go. Thus, the multiplication of partnerships by a particular host country does not necessarily increase the number of incoming students, while historical relationships are levers for international mobility.

Comparing models 1 and 2 highlight the extent to which institutional factors in host countries can influence student inflows. When these variables are added, both the R-squared and the constant increase: while in Model 1 the constant is significant only at $5 \%$, suggesting that there is a slight bias due to omitted variables, it becomes significant at the $0.1 \%$ level in Model 2. These two results confirm the idea that institutional factors in the host countries are good predictors of students inflows.

Regarding educational costs, we choose to measure them by another variable than fees at destination for two reasons. Firstly, data on fees paid by mobile students vary across EU countries and they are not available (Beine et al., 2014). Secondly, EMA2 programmes allow students to be exempted from fees at destination. Against this background, we consider that there are other costs incurred by students than direct costs like fees. Therefore, the Price Level Index is a proxy for actual consumption expenses in host countries by using Purchasing Power Parity (PPP). Since they measure extra-costs that are embodied in educational costs, we expect this variable to have a negative effect on student flows. Surprisingly, the variable has a significant but positive effect when only economic and size factors are taken into account (Model 1). Conversely, it becomes insignificant and negative when institutional factors are considered (Model 2). One possible reason is that the Price Level Index captures quality and standard of living in the host country: quality in life environment, good amenities or institutions (public administration or services, health, transport, etc.). When the model does not integrate such considerations, Price Level Index captures all these effects. Since students are more sensitive to the quality dimension in host countries, then the variable of living cost is significant and positive in Model 1. In contrast, when quality considerations are integrated in Model 2, the Price Level Index is no longer a proxy of "host" quality 
Table 5: Determinant of HE mobility: Role of host monodic factors

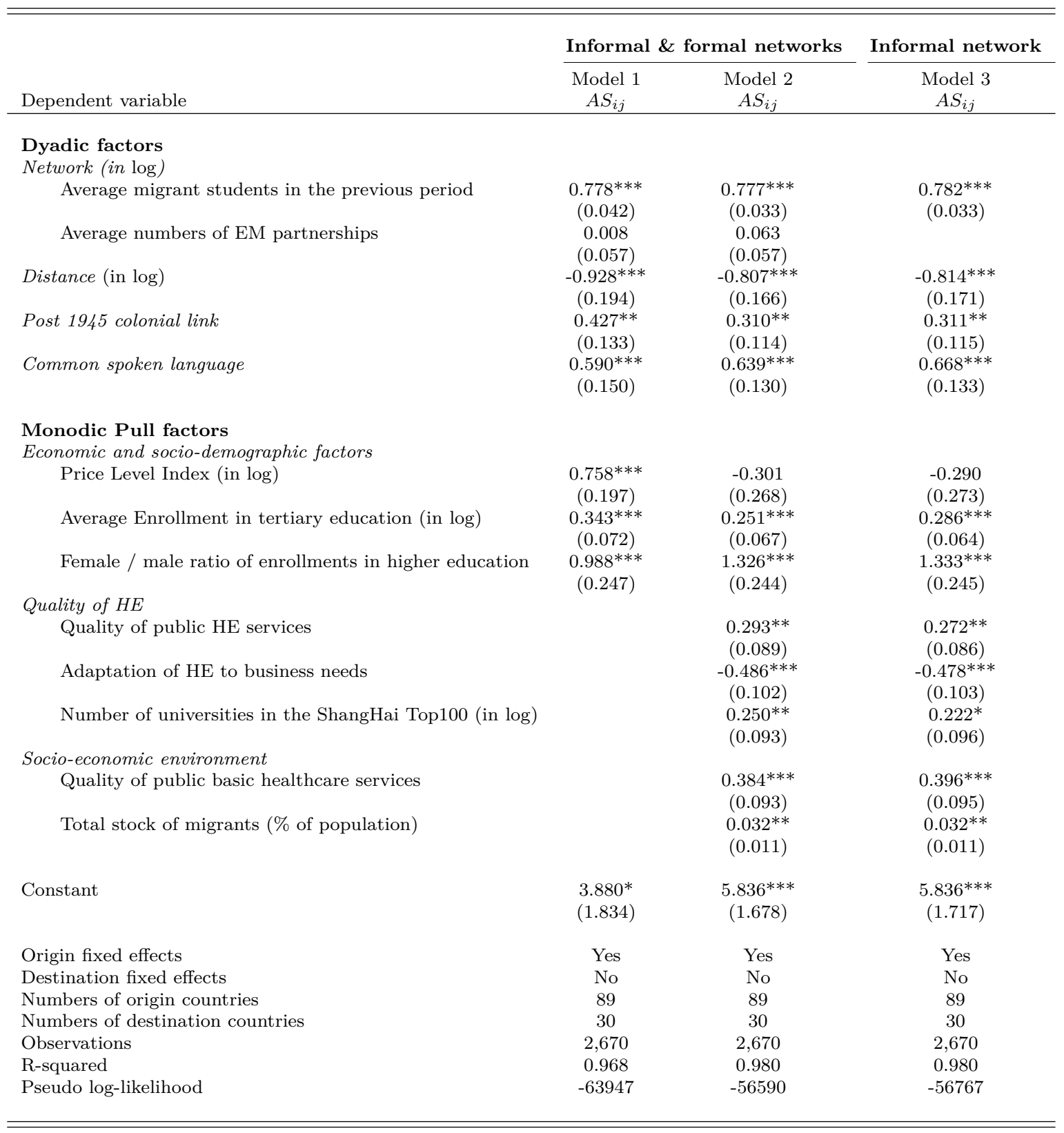

Clustered and Robust standard errors in parentheses. $\quad{ }^{* * *} \mathrm{p}<0.001,{ }^{* *} \mathrm{p}<0.01,{ }^{*} \mathrm{p}<0.05,+\mathrm{p}<0.1$ 
but only gives to students a consumption perspective. Therefore, the coefficient which is associated becomes negative but insignificant, suggesting that the institutional quality in host countries determines student flows more strongly than living costs.

Concerning socio-demographic variables, the Enrollments variable has a highly significant and positive effect: the higher the number of enrolled students at destination, the bigger the number of student inflows. Our finding provides two pieces of information on international student mobility. Firstly, from the point of view of host countries, a positive sign means that the country size is a determining factor in the absorptive capacity of student inflows coming from abroad. The larger the host country, the bigger the tertiary education system will be and the more students it can receive. Secondly, from the point of view of internationally mobile students, the size of the host capacity affects positively location choices in the fact that positive effects of student agglomeration outweigh negative effects of congestion. Like informal networks, concentration of students benefits to new entrants through easier access to information and lower indirect costs of mobility. Moreover, student "clustering" favors the development of facilities and infrastructure close to universities (transportation, restoration, housing, culture, leisure, etc.) and whose advantages seem to influence destination choices.

Similarly, Female / male ratio allows us to consider gender aspects. The coefficient has a positive and significant effect: the more host universities will be feminized, the more students coming from LMI countries will be attracted. This positive role of gender can influence destination choices of female students from home countries.

In addition to the quality dimension already highlighted on the push side, we add here universities ranking on the pull side. Such rankings are well known from students who have to choose among destination countries. The Quality of public HE services and the Number of universities in the Shanghai Top100 both provide quality considerations. The former variable is an indicator of intrinsic quality of HEIs while the latter variable measures the role of extrinsic quality, i.e. reputation effects transmitted by the various international rankings whose Shanghai ranking is undoubtedly the best known. These two variables are positive and significant at $1 \%$, implying that students from LMI countries are more sensitive to the quality dimension in host countries them at home. On the opposite, the variable about Adaptation of HE to business needs has a significant but negative effect on inflows of students. This may be related to their expectations about specific knowledge. Since internationally mobile students are not destined to stay at destination to get a job after graduation, it is not surprising that they do not consider the HE programmes which are adapted to the local characteristics. On the contrary, they choose theoretical and technical courses whose contents are easily exported at home.

Notice that comparison between Models 2 and 3 makes it possible to understand pull factors in the specific inflows of students through informal networks or alternatively, the relevant outcome owing to formal partnerships. We note that the only change occurs in the Number of universities in the ShangHai Top100 whose significance increases from the 5\% level (Model 3) to the $1 \%$ level (Model 2). Given that more and more institutions are integrating formal networks like EMA2 programmes, reputation effects become of high concern in internationalization of HE for two reasons: (i) reputation resulting from this type of ranking allows the students to prioritize the different formal networks at disposal, (ii) since formal networks are levers of reputation, countries that previously enjoyed high visibility from students are now forced to reinforce the impact of rankings to keep their reputation advantages.

Finally, socio-economic environment is taken into account. The Quality of public basic healthcare services provides information about public facilities and social insurance available to migrant students. We find a significant and positive effect of this variable: students are likely to move to countries with relatively good public facilities. While this suggests a controversial "welfare magnet" hypothesis in the economics of immigration (i.e. migrants are attracted to destinations based on the generosity of public assistance programmes), our investigation with alternative variables shows that it is not true for internationally mobile students (no significance in the share of GDP of public assistance programme, public expenditures). Moreover, two other reasons may explain this positive relationship: this variable plays as a pull factor because it allows students to reduce uncertainty about their prospects abroad, and it reflects better amenities in the destination country. The project of studying overseas is uncertain and risky, and individuals engaging in education investment must take into consideration the probability that the mobility project could fail. 
Immigration policies in host countries inevitably influence the entry of migrants into the European territories. So, the Total stock of migrants provides the migration climate in destination countries. It has another meaning than in Beine et al. (2014) where migrants are considered through a dyadic variable as a form of network. Here, we consider the total stock of migrants, regardless of the country of origin, expressed in relation to the population in the host countries. Consequently, the positive sign and the significance at $1 \%$ of this variable indicate the existence of a "welcoming land" effect. This positively affects international flows of students in two ways. Firstly, a high percentage of migrants suggests the existence of migratory facilities and generous policies towards immigrants, both in terms of administrative constraints and of acceptance of migrants by the rest of the population. Secondly, a favorable migration climate raises benefits of networks between migrants while reducing the costs of mobility (Beine et al., 2011, 2014; Bertoli and Fernández-Huertas Moraga, 2013). The fact that different specifications on networking (Model 3) are not affected by Total stock of migrants suggests that this is the first effect that prevails in our model (Model 3). Like Enrollments, the Total stock of migrants gives the absorptive capacity of migrants, and among them international students. The more host countries are able to accommodate migrants, the more they attract students.

\subsection{Combined push and pull factors}

We now analyze the complete model by removing country dummies at both sides. Interactions between push and pull factors will allow us to determine the demand for HE mobility from developing countries to Europe. Results are reported in Table 6.

Looking at the dyadic factors, the elasticity of informal network remains high even when we capture the role of factors that are origin and destination specific. Besides that, Post-colonial link becomes insignificant in comparison to Table 5: in other words, historical ties (and shared language) do not explain (or less) inflows of students when home dummies are removed. At first glance, many countries control students? abilities before their entry, in particular linguistic skills. For example, it is the case for all countries in the Erasmus Mundus programme or also when a student applies for tertiary enrollment in France through Campus France. However, it is less significant when other considerations at home and in destination are taken into account.

Moving to the country-specific factors, previous results are majorly reinforced but with some exceptions. Firstly, economic and socio-demographic factors both at home and in destination affect significantly HE mobility. While GDP per capita at the origin is still significant but at a lesser magnitude, the circular effect in origin countries becomes significant at $5 \%$ level when both formal and informal networks are under consideration. On the host side, living costs (proxied by the price index) becomes significant, predicting that international students are less likely to move to areas with a high cost of living. Interestingly, the elasticity of gender is reinforced while the host capacity effect shows the opposite, whether we consider informal networks or both formal and informal. Enrollments in tertiary education at both side reflect clearly a "youth bulge" (or cohort effect) in developing source countries which matches a size or capacity effect in host European countries.

Secondly, qualitative information on political institutions, social cohesion and quality still matter, and they even gain in importance. In sending countries for example, Irregularities in obtaining university degrees push even further students to becoming mobile internationally. In receiving countries, both indicators of quality and socio-economic environment show greater elasticity, whatever the specification of networking. Interestingly, universities ranking becomes less significant in explaining HE mobility compared to Table 5. On the opposite, quality of public HE and basic healthcare services appear to be important pull factors in our sample of European countries: the availability and quality of public services affect whether people move there. Finally, the elasticity of the Stock of migrants is also higher in the complete model, whatever the networks. This pull factor is highly significant in influencing student inflows: it provides a signal to potential migrants about relative conditions in a destination and, by a cumulative causation effect, some of the most immigrant-intensive countries turn out to become well-known immigrant destinations, including for internationally mobile students. 
Table 6: Determinant of HE mobility: Complete model

\begin{tabular}{|c|c|c|c|}
\hline \multirow[b]{2}{*}{ Dependent variable } & \multicolumn{2}{|c|}{ Informal \& formal networks } & \multirow{2}{*}{$\begin{array}{c}\text { Informal network } \\
\text { Model } 3 \\
A S_{i j}\end{array}$} \\
\hline & $\begin{array}{c}\text { Model } 1 \\
A S_{i j}\end{array}$ & $\begin{array}{l}\text { Model } 2 \\
A S_{i j}\end{array}$ & \\
\hline \multicolumn{4}{|l|}{ Dyadic factors } \\
\hline \multicolumn{4}{|l|}{ Network (in log) } \\
\hline Average migrant students in the previous period & $\begin{array}{c}0.826^{* * *} \\
(0.037)\end{array}$ & $\begin{array}{c}0.817^{* * * *} \\
(0.026)\end{array}$ & $\begin{array}{c}0.833^{* * *} \\
(0.026)\end{array}$ \\
\hline Average numbers of EM partnerships & $\begin{array}{c}0.052 \\
(0.049)\end{array}$ & $\begin{array}{l}0.086^{*} \\
(0.037)\end{array}$ & \\
\hline Distance (in log) & $\begin{array}{c}-0.216^{* *} \\
(0.069)\end{array}$ & $\begin{array}{c}-0.201^{* *} \\
(0.064)\end{array}$ & $\begin{array}{c}-0.206 * * * \\
(0.062)\end{array}$ \\
\hline Post 1945 colonial link & $\begin{array}{c}0.147 \\
(0.146)\end{array}$ & $\begin{array}{c}0.128 \\
(0.102)\end{array}$ & $\begin{array}{c}0.121 \\
(0.103)\end{array}$ \\
\hline Common spoken language & $\begin{array}{c}0.086 \\
(0.187)\end{array}$ & $\begin{array}{l}0.325^{*} \\
(0.159)\end{array}$ & $\begin{array}{l}0.289+ \\
(0.155)\end{array}$ \\
\hline \multicolumn{4}{|l|}{ Monodic Push factors } \\
\hline GDP per capita in 2004 (in log) & $\begin{array}{c}-0.106+ \\
(0.059)\end{array}$ & $\begin{array}{c}-0.136^{* *} \\
(0.051)\end{array}$ & $\begin{array}{c}-0.118^{*} \\
(0.053)\end{array}$ \\
\hline Young unemployment (\% of total labor force ages 15-24) & $\begin{array}{c}-0.015^{* *} \\
(0.005)\end{array}$ & $\begin{array}{c}-0.011^{*} \\
(0.005)\end{array}$ & $\begin{array}{c}-0.009+ \\
(0.005)\end{array}$ \\
\hline Average Enrollment in tertiary education (in log) & $\begin{array}{l}0.224^{* * *} \\
(0.039)\end{array}$ & $\begin{array}{l}0.220^{* * *} \\
(0.032)\end{array}$ & $\begin{array}{c}0.242^{* * *} \\
(0.027)\end{array}$ \\
\hline Internationally mobile students coming from host countries & $\begin{array}{l}-0.041^{*} \\
(0.016)\end{array}$ & $\begin{array}{l}-0.030^{*} \\
(0.014)\end{array}$ & $\begin{array}{c}-0.040^{* *} \\
(0.014)\end{array}$ \\
\hline \multicolumn{4}{|l|}{ Political environment and institutional factors } \\
\hline Internal conflicts & & $\begin{array}{c}-0.135^{* *} \\
(0.049)\end{array}$ & $\begin{array}{c}-0.108^{*} \\
(0.051)\end{array}$ \\
\hline Internal tensions caused by neighboring countries & & $\begin{array}{l}-0.042 \\
(0.031)\end{array}$ & $\begin{array}{l}-0.046 \\
(0.029)\end{array}$ \\
\hline Freedom to leave the country & & $\begin{array}{l}-0.051 \\
(0.079)\end{array}$ & $\begin{array}{l}-0.083 \\
(0.082)\end{array}$ \\
\hline International/regional integration_i & & $\begin{array}{c}0.003 \\
(0.042)\end{array}$ & $\begin{array}{c}0.007 \\
(0.040)\end{array}$ \\
\hline \multicolumn{4}{|l|}{ Quality of $H E$} \\
\hline Quality of public HE services & & $\begin{array}{c}0.061 \\
(0.045)\end{array}$ & $\begin{array}{c}0.050 \\
(0.045)\end{array}$ \\
\hline Adaptation of $\mathrm{HE}$ to business needs & & $\begin{array}{l}-0.057 \\
(0.053)\end{array}$ & $\begin{array}{l}-0.034 \\
(0.053)\end{array}$ \\
\hline \multicolumn{4}{|l|}{ Students' beliefs } \\
\hline Prospect for young people & & $\begin{array}{l}0.084+ \\
(0.045)\end{array}$ & $\begin{array}{l}0.088+ \\
(0.045)\end{array}$ \\
\hline Irregularities in obtaining university degrees & & $\begin{array}{c}0.161^{* * *} \\
(0.038)\end{array}$ & $\begin{array}{c}0.164^{* * *} \\
(0.038)\end{array}$ \\
\hline Importance of merit to upward social mobility & & $\begin{array}{c}0.111^{*} \\
(0.045)\end{array}$ & $\begin{array}{c}0.127^{* *} \\
(0.046)\end{array}$ \\
\hline Reluctance of firms to hire university graduates & & $\begin{array}{l}-0.000 \\
(0.036)\end{array}$ & $\begin{array}{l}-0.027 \\
(0.035)\end{array}$ \\
\hline \multicolumn{4}{|l|}{$\begin{array}{l}\text { Monodic Pull factors } \\
\text { Economic and socio-demographic factors }\end{array}$} \\
\hline Price Level Index (in log) & $\begin{array}{c}0.297 \\
(0.192)\end{array}$ & $\begin{array}{l}-0.908^{* * *} \\
(0.266)\end{array}$ & $\begin{array}{c}-0.886^{* *} \\
(0.271)\end{array}$ \\
\hline Average Enrollment in tertiary education (in log) & $\begin{array}{c}0.258^{* * *} \\
(0.068)\end{array}$ & $\begin{array}{c}0.199 * * * \\
(0.058)\end{array}$ & $\begin{array}{c}0.242^{* * *} \\
(0.058)\end{array}$ \\
\hline Female / male ratio of enrollments in higher education & $\begin{array}{c}1.454^{* * *} \\
(0.251)\end{array}$ & $\begin{array}{c}1.742^{* * *} \\
(0.252)\end{array}$ & $\begin{array}{c}1.792^{* * *} * \\
(0.264)\end{array}$ \\
\hline
\end{tabular}


Table 6: Determinant of higher education mobility: Complete model (continued)

\begin{tabular}{|c|c|c|c|}
\hline \multirow[b]{2}{*}{ Dependent variable } & \multicolumn{2}{|c|}{ Informal \& formal networks } & \multirow{2}{*}{$\begin{array}{c}\text { Informal network } \\
\text { Model } 3 \\
A S_{i j}\end{array}$} \\
\hline & $\begin{array}{c}\text { Model } 1 \\
A S_{i j}\end{array}$ & $\begin{array}{c}\text { Model } 2 \\
A S_{i j}\end{array}$ & \\
\hline \multicolumn{4}{|l|}{ Quality of $H E$} \\
\hline Quality of public HE services & & $\begin{array}{c}0.432^{* * *} \\
(0.084)\end{array}$ & $\begin{array}{c}0.382^{* * *} \\
(0.083)\end{array}$ \\
\hline Adaptation of $\mathrm{HE}$ to business needs & & $\begin{array}{c}-0.604^{* * *} \\
(0.129)\end{array}$ & $\begin{array}{c}-0.601 * * * \\
(0.128)\end{array}$ \\
\hline Number of universities in the ShangHai Top100 (in log) & & $\begin{array}{c}0.255^{*} \\
(0.112)\end{array}$ & $\begin{array}{l}0.204+ \\
(0.115)\end{array}$ \\
\hline \multicolumn{4}{|l|}{ Socio-economic environment } \\
\hline Quality of public basic healthcare services & & $\begin{array}{c}0.428^{* * *} \\
(0.091)\end{array}$ & $\begin{array}{c}0.459^{* * *} \\
(0.091)\end{array}$ \\
\hline Total stock of migrants (\% of population) & & $\begin{array}{c}0.047^{* * *} \\
(0.011)\end{array}$ & $\begin{array}{c}0.047^{* * *} \\
(0.012)\end{array}$ \\
\hline Constant & $\begin{array}{c}1.372 \\
(1.101)\end{array}$ & $\begin{array}{c}7.196^{* * *} \\
(1.561)\end{array}$ & $\begin{array}{c}7.318^{* * *} \\
(1.498)\end{array}$ \\
\hline Origin fixed effects & No & No & No \\
\hline Destination fixed effects & No & No & No \\
\hline Numbers of origin country & 81 & 79 & 79 \\
\hline Numbers of destination country & 30 & 30 & 30 \\
\hline Observations & 2,430 & 2,370 & 2,370 \\
\hline R-squared & 0.935 & 0.966 & 0.967 \\
\hline Pseudo log-likelihood & -96482 & -75967 & -77044 \\
\hline
\end{tabular}

Clustered and Robust standard errors in parentheses. $\quad * * * \mathrm{p}<0.001,{ }^{* *} \mathrm{p}<0.01,{ }^{*} \mathrm{p}<0.05,+\mathrm{p}<0.1$

\section{Discussion}

This complete model allows us to answer to the three research questions which were addressed in Introduction. Factors that are origin specific help us to understand the main motivations for students from developing countries to go abroad. In complement, factors that are destination specific allow us to understand what can pull or attract internationally mobile students in the European countries and, therefore, shed light on attractiveness.

Firstly, moving is costly, and not everyone is able to afford to study abroad. Any student that decides to attend a HE programme abroad incurs higher costs than the sole enrollment fees charged by the host institution. Dyadic factors have highlighted mobility costs associated to geographic or cultural and linguistic distances, but the economic variables of LMI and European countries reinforce this main idea. Only individuals who can save or have enough income will be able to move abroad for a while; the poorest students may not be able to do it, even though they have the most to gain by doing so. In the light of this, networks are important in reducing migration costs because they pass along information and feedback about how to move and where to go.

Living costs measured here by the Price Level Index are extra costs that may compensate for direct educational costs; but on the other hand, they may also signal better conditions in the host country. If students are only guided by economic considerations, our empirical investigation shows that good and attractive amenities (good urban transport, public administration, housing, life environment) that are behind a price index influence positively international mobility. Advanced countries within the EU aptly illustrate this positive relationship (UK, Germany, France among them). However, the latter aspect is compensated by other considerations, allowing us to argue that non-monetary variables are of greater importance in determining a country's attractiveness.

Secondly, from the Southern perspective, the capacity of HEIs to host internationally mobile students is an influencing factor; so does gender equity. It is particularly relevant for developing countries where, in the face of supply shortage in HE, the demographic pressure (a "youth bulge" with high numbers of enrolled students) could be solved at the short term by outflows of tertiary 
level students. In turn, the circular flow of students may help to build learning capacity in the origin country, contributing to increase stayers through brain gain.

Thirdly, consistent with Van Bouwel and Veugelers (2013), our study finds that internationally mobile students are more sensitive to the quality dimension in host countries, but specifically in the signaling perspective to education. Indeed, high-quality institutions with good services and "prestige" will attract students. In contrast, the extent to which HE are adapted to business needs in the host country does not attract them. This finding supports the investment perspective of HE: students from LMI countries are not influenced by the employability of hosting HE programmes, but only by their learning capacity.

Lastly, migration climate, as well as good amenities (availability and quality of healthcare or other public services), are positive pull factors of internationally mobile students. This result may support a "cumulative causation" of migration which implies controversial policy recommendations. On one hand, people who oppose immigration may find here relevant arguments for imposing restrictions on entries. But on the other hand, one may counter-argue that our targets here are immigrants who are skilled people staying to study for a while and therefore, they do not have any permanent influence on the host countries. In fact, countries in the EU have already relatively strict policies for immigration by non-EU citizens. Therefore, transnational cooperation based on institutional partnership is already a way to control for admission policies, i.e. immigration policies. Moreover, our paper finds strong evidence of network effects in migrating, particularly of informal or social ties in assisting students outflows. However, migration incentives become endogenous once network effects are introduced (Docquier and Sekkat, 2006). Those legal temporary migrants are only one group of immigrants and further restrictions on their entries may even create a counterproductive effect. Indeed, restrictive immigration policies, by raising quality and availability in public HE services make this pull factor even stronger (the destination country becomes more attractive), thereby developing the effect of networks in determining student inflows.

\section{Conclusion and remarks}

Migration is a feature of the ongoing globalization process, but the profile of migrant populations varies considerably depending on the variety of sources of migration. In this paper, we have analyzed the determinants of demand for HE mobility of students from low- and middle-income countries to Europe over the period 2004-2013. The main finding of existing studies on the topic is that student mobility is governed by geographic and cultural distances, as emphasized in usual gravity empirics. However, our study highlights other factors which influence the choice of HE from different perspectives: either in multilateral resistance to migration or in country-specific factors.

In comparison to the existing studies, our empirical investigation attempts to better understand multilateral resistance by highlighting two aspects. First, the literature on foreign language skills majorly uses a single measure of linguistic relationship. However, it may not reflect the diverse sources of linguistic influence on student mobility. Similarly, most studies on the topic consider networking either by using total migrant stocks from the origin living at destination or member states of Bologna Process. Our study attempts to fill the gap by comparing different measures of networks which are of growing interest in developing countries: on the one hand, informal network coming from friendship and social interactions with former students and on the other hand, formal partnerships between HEIs. In this context, the Erasmus Mundus programme (EMA2) is one among many instruments which are dedicated to control or choose migrants. This explains the rapid development of these programmes and why it has gradually become the only opportunity for students to enter the destination country.

Our findings on dyadic resistance to migration show a positive impact from linguistic relations and networks effects which lower mobility costs when a student has to consider enrollment abroad. Particularly, CSL is the most important linguistic resistance to student mobility. This result can be put into a double perspective: of language skills level in origin countries and of restrictive admission conditions for candidates in host countries, and more precisely of the selection that takes place before student move.

On the other side, we have shown that the Average number of migrant students in the previous period is a good proxy for informal networks. The elasticity of this variable appears to be high, meaning that feedback from former migrant students turns out to have important contribution 
in reducing multilateral resistance to student mobility. Lastly, a measure of formal networks by the number of Erasmus Mundus partnerships between sending and receiving countries has been proposed. We consider that these formal networks will take growing importance in the distribution of student inflows as they constitute an immigration policy that allows only international students with some education or linguistic skills requirements to be eligible. It is the reason why the variable is sensitive to linguistic variables or Colonial link, that are themselves at the heart of immigration policy. As expected, Distance and Colonial link have significant effects, but lower than those usually accepted in the economic literature.

Once we have examined the dyadic factors, this paper moves on to analyze country-specific factors at origin (push factors) and at destination (pull factors).

By focusing on the role of different monodic home factors in HE mobility, we make an important contribution to the literature. Overall, both institutional and economic factors appear to be important push factors in our country sample of developing countries. Most existing studies address the role of access to educational opportunities at home to control for the possibility that students are forced to seek HE overseas. In our paper, such educational opportunities are captured at macroeconomic level by income at home, the number of Internationally mobile students coming from host countries, Enrollments in tertiary education. Moreover, we have also investigated other institutional factors and students? beliefs. In addition to the cohort effect, it appears that disappointing perception on universities degrees or difficulty to gain merit at home push students into becoming mobile. In other words, qualitative and direct information on the "de facto" outcome of rules, public institutions or service delivery strongly influence HE mobility.

Factors that are destination specific allow us to understand what can pull or attract internationally mobile students in the European countries and, therefore, suggest some policy implications in terms of attractiveness. Our results show that students are guided by economic considerations like living costs. However, the latter aspect is compensated by other considerations, allowing us to argue that non-monetary variables are of greater importance in determining a country's attractiveness.

Assuming that the number of enrollments in HE is a proxy for the host capacity, we found that it is a pull factor. Gender aspects also explain student inflows from developing countries, as well as quality in public HE and basic healthcare services. Attractive amenities appear to be an important pull factor in our sample of European countries: the availability and quality of public services affect whether people move there.

Stock of migrants is a good predictor of student inflows (and immigration flows in general), enabling some studies to talk about cumulative causation of migration. Out of describing a network effect, it signals to potential migrants about relative conditions in migratory facilities, life environment in destination countries. In the face of such cumulative causation, European countries may become sensitive to the ongoing debate on immigration restrictions. Our paper provides crosssectional evidence that students who are "socially" connected either informally (with their friends, diasporas or former students enrolled abroad) or formally (through institutional partnerships between their HEIs) are more prone to leave their country of origin. Understanding these impacts is important if EU countries want to usefully debate the role of migration as a part of globalization process. Migration is not only driven by workforce needs. In particular, the EMA2 programme could be used as a tool to shape the characteristics of student inflows through admission or eligibility criteria. In the face of global competition, the ability of a country to attract talent from around the world enhance local human capital; but such discrimination among students migrants (when immigration policies are coupled with quality selective criteria) may raise legal and moral doubts. More interestingly, the European countries could promote transnational cooperation in a more "brain circulation" perspective. Network effects coupled with outflow of students and staff in destination to non-EU countries help to develop local learning and teaching capacities while alleviating students exit. Such debates are essential to designing policies in areas like HE.

\section{References}

Appelt, S., van Beuzekom, B., Galindo-Rueda, F., and de Pinho, R. (2015). Which factors influence the international mobility of research scientists? OECD Science, Technology and Industry Working Papers, 2015/02. 
Bansak, C., Simpson, N. B., and Zavodny, M. (2015). The Economics of Immigration. Routledge, 2015th edition.

Beech, S. E. (2015). International student mobility: the role of social networks. Social \& Cultural Geography, 16(3):332-350.

Beine, M., Bertoli, S., and Fernández-Huertas Moraga, J. (2016). A practitioners' guide to gravity models of international migration. The World Economy, 39(4):496-512.

Beine, M., Docquier, F., and Ozden, C. (2011). Diasporas. Journal of Development Economics, 95(1):30 - 41. Symposium on Globalization and Brain Drain.

Beine, M., Noel, R., and Ragot, L. (2013). The determinants of international mobility of students. Working Papers 2013-30, CEPII.

Beine, M., Noel, R., and Ragot, L. (2014). Determinants of the international mobility of students. Economics of Education Review, 41:40 - 54.

Bertoli, S. and Fernández-Huertas Moraga, J. (2013). Multilateral resistance to migration. Journal of Development Economics, 102:79 - 100. Migration and Development.

Bertoli, S. and Fernández-Huertas Moraga, J. (2015). The size of the cliff at the border. Regional Science and Urban Economics, 51:1 - 6 .

Brooks, R. and Waters, J. (2010). Social networks and educational mobility: the experiences of uk students. Globalisation, Societies and Education, 8(1):143-157.

Clark, X., Hatton, T. J., and Williamson, J. G. (2007). Explaining u.s. immigration, 1971-1998. Review of Economics and Statistics, 89(2):359 - 373.

Coniglio and Kondoh (2015). International integration with heterogeneous immigration policies. International Economics, 142:15-31.

Docquier, F. and Sekkat, K. (2006). The Brain Drain: What do we know? Number 31 in AFD Working Paper. Agence Française du Développement.

Grogger, J. and Hanson, G. H. (2011). Income maximization and the selection and sorting of international migrants. Journal of Development Economics, 95(1):42 - 57. Symposium on Globalization and Brain Drain.

Hatton, T. J. and Williamson, J. G. (2005). What fundamentals drive world migration? In Borjas, G. J. and Crsp, J., editors, Poverty, International Migration and Asylum. Palgrave Macmilla, Hampshire, UK.

Head, K., Mayer, T., and Ries, J. (2010). The erosion of colonial trade linkages after independence. Journal of International Economics, 81(1):1 - 14.

Mayda, A. M. (2010). International migration: a panel data analysis of the determinants of bilateral flows. Journal of Population Economics, 23(4):1249-1274.

Mazzarol, T. and Soutar, G. N. (2002). Push-pull factors influencing international student destination choice. International Journal of Educational Management, 16(2):82-90.

Melitz, J. and Toubal, F. (2014). Native language, spoken language, translation and trade. Journal of International Economics, 93(2):351 - 363.

Melitz, J. and Toubal, F. (2016). Faut-il parler la même langue pour commercer? La lettre du CEPII, (361).

Naidoo, V. (2007). Research on the flow of international students to uk universities: Determinants and implications. Journal of Research in International Education, 6(3):287-307. 
OECD (2009). Higher Education to 2030, Vol 2. Globalisation. Centre for Education Research and Innovation.

Ortega, F. and Peri, G. (2013). The effect of income and immigration policies on international migration. Migration Studies, 1(1):47-74.

Pedersen, P. J., Pytlikova, M., and Smith, N. (2008). Selection and network effects-migration flows into \{OECD\} countries 1990-2000. European Economic Review, 52(7):1160 - 1186.

Pedro, E. and Franco, M. (2016). The importance of networks in the transnational mobility of higher education students: attraction and satisfaction of foreign mobility students at a public university. Studies in Higher Education, 41(9):1627-1655.

Rodriguez Gonzalez, C., Bustillo Mesanza, R., and Mariel, P. (2011). The determinants of international student mobility flows: an empirical study on the erasmus programme. Higher Education, $62(4): 413-430$.

Shepherd, B. (2012). The Gravity Model of International Trade: A User Guide. Number BRR11 in ARTNeT Books and Research Reports. United Nations Economic and Social Commission for Asia and the Pacific (ESCAP).

Shields, R. (2013). Globalization and international student mobility: A network analysis. Comparative Education Review, 57(4):609-636.

Silva, J. a. S. and Tenreyro, S. (2006). The log of gravity. The Review of Economics and Statistics, 88(4):641-658.

Van Bouwel, L. and Veugelers, R. (2013). The determinants of student mobility in europe: the quality dimension. European Journal of Higher Education, 3(2):172-190.

van der Wendet, M. (2015). International academic mobility: Towards a concentration of the minds in europe. Research \& Occasional Paper Series, CSHE.3.14.

Vogtle, E. M. and Windzio, M. (2016). Networks of international student mobility: enlargement and consolidation of the european transnational education space? Higher Education, 72(6):723741 . 
Appendix A. Countries sample

Appendix A.1. Host countries

\begin{tabular}{ll|l}
\hline \hline \multicolumn{2}{c|}{ In the sample } & Out of the sample \\
\hline EU27 countries & Luxembourg \\
Austria & Italy & \\
Belgium & Latvia & \\
Bulgaria & Lithuania & \\
Croatia & Malta & \\
Cyprus & Netherlands & \\
Czech Republic & Poland & \\
Denmark & Portugal & \\
Estonia & Romania & \\
Finland & Slovakia & \\
France & Slovenia & \\
Germany & Spain & \\
Greece & Sweden & \\
Hungary & United Kingdom & \\
Ireland & & \\
EU+ countries & & \\
Iceland & Switzerland & \\
Norway & & \\
\hline
\end{tabular}


According to the World Bank classification, Low- and Middle-Income countries (LMIs) are those in which 2013 GNI per capita was $\$ 12,745$ or less.

Out of the 136 LMIs counted, data on bilateral flows of tertiary level students are missing for 47 countries.

\begin{tabular}{|c|c|c|}
\hline \multicolumn{2}{|c|}{ In the sample } & \multirow{2}{*}{$\begin{array}{l}\text { Out of the sample } \\
\text { American Samoa }\end{array}$} \\
\hline Afghanistan & Kenya & \\
\hline Albania & Kyrgyzstan & Belize \\
\hline Algeria & Lao P. Dem. Rep. & Bhutan \\
\hline Angola & Lebanon & Botswana \\
\hline Argentina & Liberia & Cabo Verde \\
\hline Armenia & Libya & Comoros \\
\hline Azerbaijan & Madagascar & Djibouti \\
\hline Bangladesh & Malaysia & Dominica \\
\hline Belarus & Mali & Eritrea \\
\hline Benin & Mauritania & Ethiopia \\
\hline Bolivia, Plu. State of & Mauritius & Fiji \\
\hline Bosnia and Herzegovina & Mexico & Grenada \\
\hline Brazil & Morocco & Guinea-Bissau \\
\hline Burkina Faso & Mozambique & Guyana \\
\hline Burundi & Nepal & Kiribati \\
\hline Cambodia & Nicaragua & Korea, Dem. People's Rep. \\
\hline Cameroon & Niger & Kosovo \\
\hline Central African Rep. & Nigeria & Lesotho \\
\hline Chad & Pakistan & Macedonia \\
\hline China & Panama & Malawi \\
\hline Colombia & Paraguay & Maldives \\
\hline Congo, Dem Rep. & Peru & Marshall Islands \\
\hline Congo, Rep. & Philippines & Micronesia, Fed. Sts. \\
\hline Costa Rica & Rwanda & Moldovia \\
\hline Côte d'Ivoire & Senegal & Mongolia \\
\hline Cuba & Sierra Leone & Montenegro \\
\hline Dominican Rep. & Somalia & Myanmar \\
\hline Ecuador & South Africa & Namibia \\
\hline Egypt & Sri Lanka & Palau \\
\hline El Salvador & Sudan & Papua New Guinea \\
\hline Gabon & Syrian Arab Rep. & Salomon Islands \\
\hline Gambia & Tanzania & Samoa \\
\hline Georgia & Thailand & Sao Tome and Principe \\
\hline Ghana & Togo & Serbia \\
\hline Guatemala & Tunisie & Seychelles \\
\hline Guinea & Turkey & South Sudan \\
\hline Haiti & Turkmenistan & St. Lucia \\
\hline Honduras & Uganda & St. Vincent and the Grenad. \\
\hline India & Ukraine & Suriname \\
\hline Indonesia & Uzbekistan & Swaziland \\
\hline Iran, Islamic Rep. of & Venezuela & Tajikistan \\
\hline Iraq & Viet Nam & Timor-Leste \\
\hline Jamaica & Zambia & Tonga \\
\hline Jordan & Zimbabwe & Tuvalu \\
\hline Kazakhstan & & Vanuatu \\
\hline & & West Bank and Gaza \\
\hline & & Yemen \\
\hline 89 coun & ies & 47 countries \\
\hline
\end{tabular}


Appendix B. Descriptive statics

Figure B.1: Total flows of internationally mobile students 1999-2013, in million

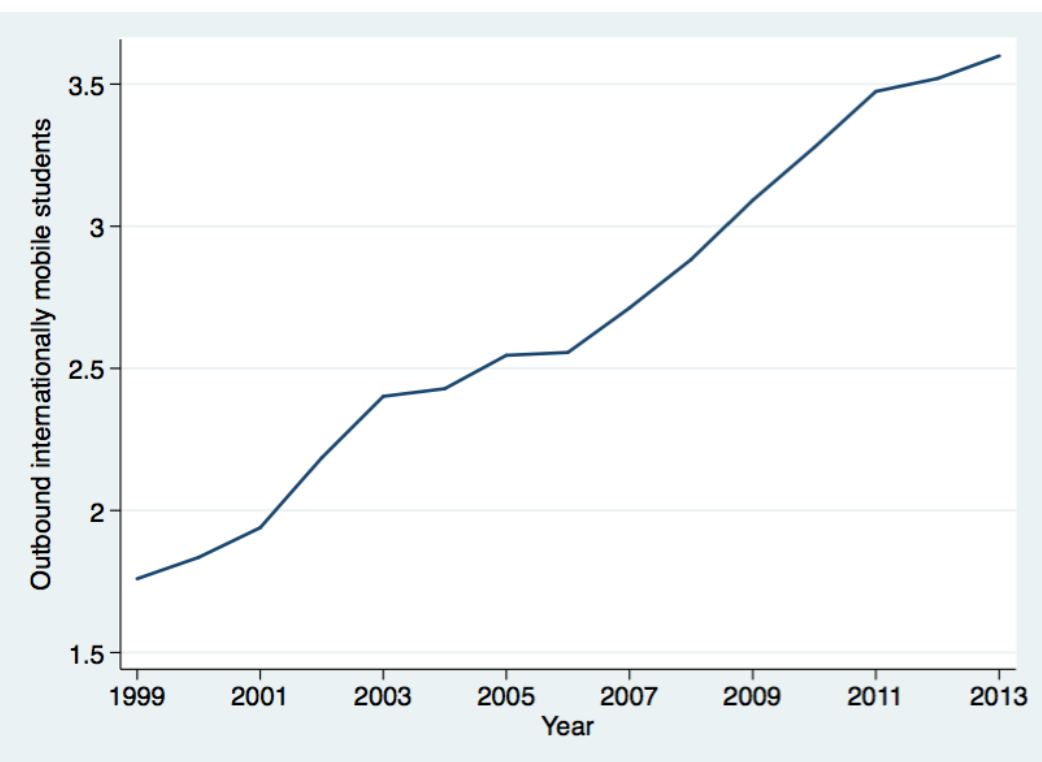

Source: UNESCO

Figure B.2: Distribution of inbound and outbound flows Cumulative flows, 1999-2013

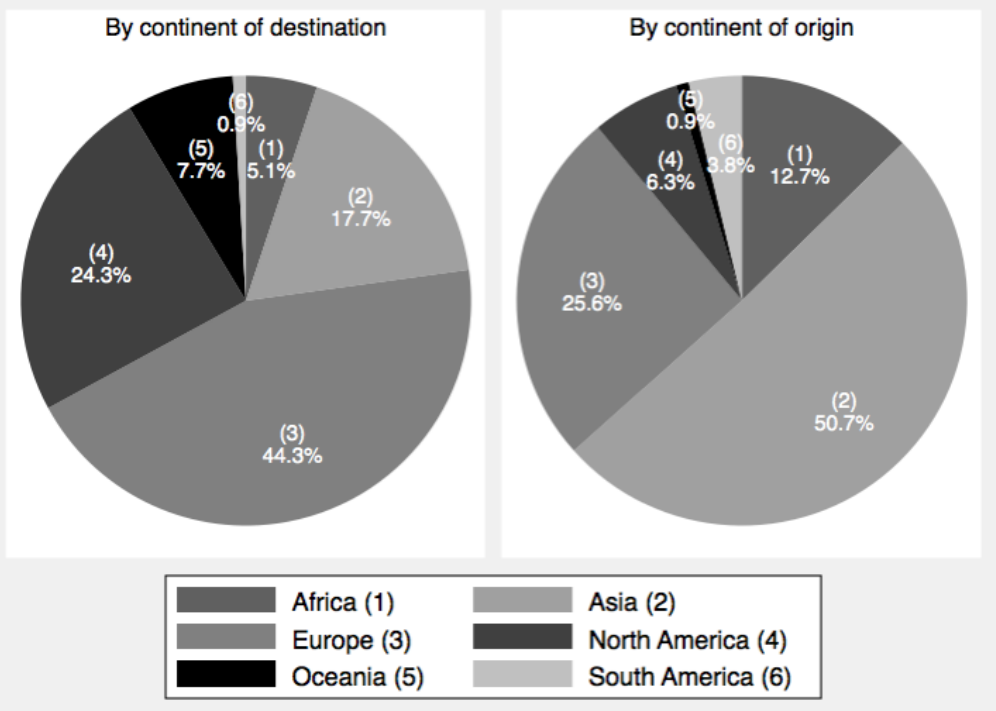

Source: UNESCO 
Figure B.3: Distribution of outbound flows

Cumulative flows, 1999-2013

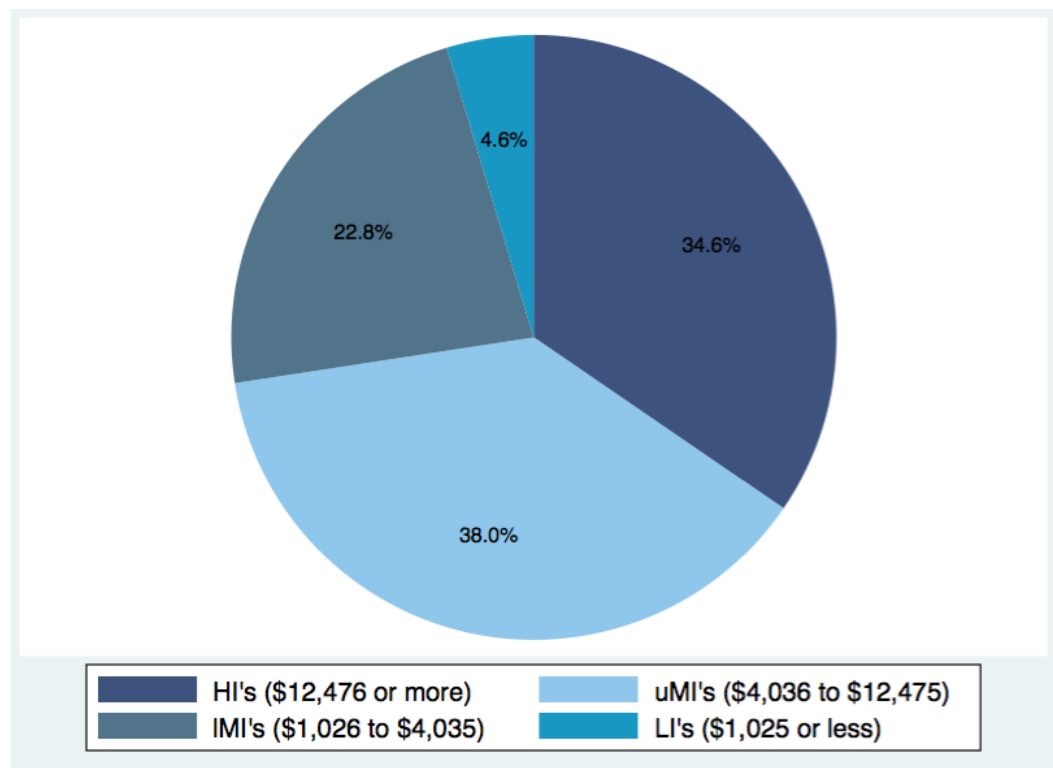

Source: UNESCO

Figure B.4: Total flows of inbound students to Europe 1999-2013, in million

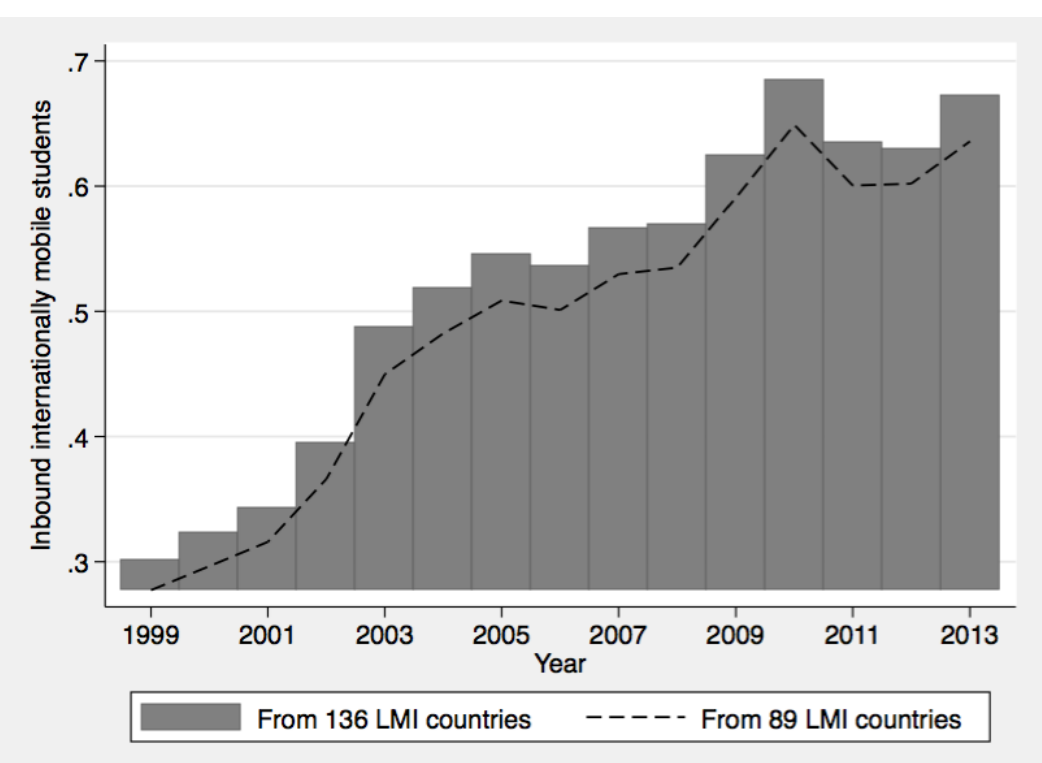

Source: UNESCO 
Appendix C. Summary statics

\begin{tabular}{|c|c|c|c|c|c|c|}
\hline Variable & Type & Mean & Std. Dev. & Min. & Max. & $\mathbf{N}$ \\
\hline \multicolumn{7}{|c|}{ Dependant variable } \\
\hline$N_{i j}$ & Continuous & 215.652 & 1665.297 & 0 & 57324.199 & 2670 \\
\hline \multicolumn{7}{|l|}{ Dyadic factors } \\
\hline migrants_ij & Continuous & 5993.318 & 51290.478 & 0 & 2008979 & 2670 \\
\hline M_ij & Continuous & 129.011 & 961.37 & 0 & 26820.6 & 2670 \\
\hline emnetwork3 & Continuous & 1.795 & 3.926 & 0 & 35.143 & 2670 \\
\hline dist & Continuous & 6224.798 & 2881.676 & 169.526 & 12971.297 & 2670 \\
\hline $\operatorname{col} 45$ & Dummy & 0.018 & 0.134 & 0 & 1 & 2670 \\
\hline $\mathrm{col}$ & Dummy & 0.053 & 0.224 & 0 & 1 & 2670 \\
\hline csl & Dummy & 0.082 & 0.158 & 0 & 1 & 2670 \\
\hline cnl & Continuous & 0.007 & 0.069 & 0 & 0.99 & 2670 \\
\hline lp1 & Continuous & 0.701 & 1.158 & 0 & 5.838 & 2670 \\
\hline \multicolumn{7}{|c|}{ Monodic Push factors } \\
\hline $\operatorname{gdp} 04 \_\mathrm{i}$ & Continuous & 4921.384 & 4114.831 & 449.396 & 20397.965 & 2670 \\
\hline youthunemp_i & Continuous & 16.469 & 11.816 & 0.700 & 56.4 & 2670 \\
\hline enrol_i & Continuous & 1.274 & 3.713 & 0.004 & 27.242 & 2430 \\
\hline Nji_i & Continuous & 90.529 & 403.674 & 0 & 3544.6 & 2670 \\
\hline A2031_i & Discrete ordered & 1.931 & 0.868 & 0 & 3 & 2610 \\
\hline A8020_i & Discrete ordered & 2.287 & 1.193 & 0 & 4 & 2610 \\
\hline A5033_i & Discrete ordered & 2.471 & 0.957 & 0 & 4 & 2610 \\
\hline A8001_i & Discrete ordered & 1.747 & 0.485 & 0 & 2 & 2610 \\
\hline D5010_i & Discrete ordered & 1.609 & 0.863 & 0 & 4 & 2610 \\
\hline D9002_i & Discrete ordered & 2.034 & 0.940 & 0 & 4 & 2610 \\
\hline A5100_i & Discrete ordered & 2.54 & 0.92 & 0 & 4 & 2610 \\
\hline D9032_i & Discrete ordered & 2.241 & 1.017 & 0 & 4 & 2610 \\
\hline D9040_i & Discrete ordered & 1.851 & 0.865 & 0 & 4 & 2610 \\
\hline D9061_i & Discrete ordered & 1.287 & 0.982 & 0 & 3 & 2610 \\
\hline \multicolumn{7}{|c|}{ Monodic Pull factors } \\
\hline PLI_j & Continuous & 92.903 & 30.564 & 41.95 & 152.38 & 2670 \\
\hline enrol_j & Continuous & 0.662 & 0.783 & 0.01 & 2.489 & 2670 \\
\hline genderratio_j & Continuous & 1.34 & 0.215 & 0.923 & 1.835 & 2670 \\
\hline D9002_j & Discrete ordered & 3.533 & 0.618 & 2 & 4 & 2670 \\
\hline ranking1_j & Continuous & 1.09 & 2.217 & 0 & 10.5 & 2670 \\
\hline D5010_j & Discrete ordered & 2.767 & 0.883 & 1 & 4 & 2670 \\
\hline D9003_j & Discrete ordered & 3.233 & 0.955 & 1 & 4 & 2670 \\
\hline migrants_j & Continuous & 10.327 & 5.63 & 0.768 & 26.501 & 2670 \\
\hline
\end{tabular}

